\title{
Mitochondrial and endoplasmic reticulum stress pathways cooperate in zearalenone-induced apoptosis of human leukemic cells
}

\author{
Ratana Banjerdpongchai ${ }^{*}$, Prachya Kongtawelert ${ }^{1}$, Orawan Khantamat ${ }^{1}$, Chantragan Srisomsap ${ }^{2}$, \\ Daranee Chokchaichamnankit², Pantipa Subhasitanont ${ }^{2}$, Jisnuson Svasti ${ }^{2,3}$
}

\begin{abstract}
Background: Zearalenone (ZEA) is a phytoestrogen from Fusarium species. The aims of the study was to identify mode of human leukemic cell death induced by ZEA and the mechanisms involved.

Methods: Cell cytotoxicity of ZEA on human leukemic HL-60, U937 and peripheral blood mononuclear cells (PBMCs) was performed by using 3-(4,5-dimethyl)-2,5-diphenyl tetrazolium bromide (MTT) assay. Reactive oxygen species production, cell cycle analysis and mitochondrial transmembrane potential reduction was determined by employing $2^{\prime}, 7^{\prime}$-dichlorofluorescein diacetate, propidium iodide and 3,3'-dihexyloxacarbocyanine iodide and flow cytometry, respectively. Caspase-3 and -8 activities were detected by using fluorogenic Asp-Glu-Val-Asp-7-amino-4methylcoumarin (DEVD-AMC) and Ile-Glu-Thr-Asp-7-amino-4-methylcoumarin (IETD-AMC) substrates, respectively. Protein expression of cytochrome c, Bax, BCl-2 and BCl-xL was performed by Western blot. The expression of proteins was assessed by two-dimensional polyacrylamide gel-electrophoresis (PAGE) coupled with LC-MS2 analysis and realtime reverse transcription polymerase chain reaction (RT-PCR) approach.

Results: ZEA was cytotoxic to U937 > HL-60 > PBMCs and caused subdiploid peaks and G1 arrest in both cell lines. Apoptosis of human leukemic HL-60 and U937 cell apoptosis induced by ZEA was via an activation of mitochondrial release of cytochrome $\mathrm{c}$ through mitochondrial transmembrane potential reduction, activation of caspase- 3 and -8 , production of reactive oxygen species and induction of endoplasmic reticulum stress. Bax was up regulated in a time-dependent manner and there was down regulation of $\mathrm{BCl}-\mathrm{xL}$ expression. Two-dimensional PAGE coupled with LC-MS2 analysis showed that ZEA treatment of HL-60 cells produced differences in the levels of 22 membrane proteins such as apoptosis inducing factor and the ER stress proteins including endoplasmic reticulum protein 29 (ERp29), $78 \mathrm{kDa}$ glucose-regulated protein, heat shock protein 90 and calreticulin, whereas only ERp29 mRNA transcript increased.
\end{abstract}

Conclusion: ZEA induced human leukemic cell apoptosis via endoplasmic stress and mitochondrial pathway.

\section{Introduction}

The phytoestrogen zearalenone (ZEA) is one of the most active naturally occurring estrogenic compounds $[1,2]$. Food, snacks, dried fruits, dried vegetables and beverages such as beer, often contain ZEA [3-5]. The average daily intake of ZEA in adults ranges from 0.8-29

\footnotetext{
* Correspondence: ratana@chiangmai.ac.th

'Department of Biochemistry, Faculty of Medicine, Chiang Mai University, Chiang Mai 50200, Thailand

Full list of author information is available at the end of the article
}

ng/kg body weight (b.w.)/day, while small children have a higher average daily intake, 6-55 ng/kg b.w./day [6].

Treatment with Zea $(10-40 \mu \mathrm{M})$ of Vero, Caco-2 and DOK cells results in apoptosis as evidenced by DNA ladder formation and presence of apoptotic bodies [7]. Recently, ZEA has been shown to induce apoptosis in human hepatocytes (HepG2) via p53-dependent mitochondrial signaling pathway with the up regulation of ATM and GADD45 involved in DNA repair [8].

In mammalian cells, there are two major pathways involved in apoptosis: mitochondria-initiated intrinsic

\section{() Biomed Central}


pathway and death receptor-stimulated extrinsic pathway [9-11]. In the former pathway, proapoptotic signals provoke release from mitochondrial inter-membranous space into cytosol of cytochrome c, which forms a complex with Apaf-1 and dATP, known as apoptosome, and triggers caspase- 9 activation. Activation of caspase- 9 leads to subsequent activation of executioner caspases, such as caspase-3, -6, -7, which in turn stimulates a series of apoptotic events, eventually leading to cell death $[9,12,13]$. The extrinsic pathway begins with binding of Fas ligand to Fas death receptor, and an adaptor molecule is recruited to the receptor, which allows binding and proteolytic activation of caspase-8. Activated caspase- 8 then cleaves effector caspase- $3,-6$ and -7 , leading to apoptotic cell death $[10,12,14]$.

In addition to the above mentioned pathways, apoptosis can be induced via endoplasmic reticulum (ER), which normally regulates protein synthesis and intracellular calcium $\left(\mathrm{Ca}^{2+}\right)$ homeostasis [15]. Excessive ER stress triggers apoptosis through a variety of mechanisms including redox imbalance, alteration in $\mathrm{Ca}^{2+}$ level and activation of Bcl-2 family proteins [16].

Calreticulin (CRT) is an abundant $\mathrm{Ca}^{2+}$-binding chaperone, which is mostly present in ER lumen, although it can also be found in other subcellular localizations $[17,18]$. When present on the surface of damaged cells, it can serve as an 'eat-me' signal and hence facilitates the recognition and later engulfment of dying cells by macrophages [19] or by dendritic cells [20]. It is thought that this function determines the immunostimulatory effect of CRT, as presentation of tumor antigens by dendritic cells is required for the immunogenic effect of anthracyclin-treated cancer cells [20-22]. Alternatively, CRT may bind tumor antigenic peptides and facilitate their efficient presentation to $\mathrm{T}$ cells [23]. Crosstalk with the two well-characterized apoptotic pathways also exists, since ER stress can also activate caspase- 8 and caspase-9 $[24,25]$.

The ability of ZEA to modulate leukemic cell growth has not yet been well characterized. Using two human leukemic HL-60 and U937 cell lines we found that human leukemic cell apoptosis induced by ZEA was related to caspase- 3 and -8 activation, mitochondrial transmembrane potential (MTP) reduction and cytochrome $\mathrm{c}$ release. ZEA also induced oxidative stress via ROS generation, Bax upregulation and $\mathrm{Bcl}-\mathrm{xL}$ downregulation. The mechanistic effect also involved increased $\mathrm{Ca}^{2+}$ concentration in cytosol and mitochondria indicating ER stress but there was no calreticulin exposure on the cell surface at $30 \mathrm{~min}$. Two-dimensional gel-electrophoresis of proteins following $24 \mathrm{~h}$ treatment revealed upregulated expression of ER-mediated chaperone endoplasmic reticulum protein 29 (ERp29), $78 \mathrm{kDa}$ glucose regulated protein (GRP78), and calreticulin supporting the involvement of ER stress.

\section{Materials and methods \\ Chemicals and test media}

ZEA (Figure 1), lymphoprep, MTT (3-(4,5-dimethyl)-2,5diphenyl tetrazolium bromide, propidium iodide (PI), 3,3'-dihexyloxacarbocyanine iodide $\left(\mathrm{DiOC}_{6}\right), 2^{\prime}, 7^{\prime}$ dichlorofluorescein diacetate (DCFH-DA), ProteoExtract Albumin/Removal kit, and ProteoPrep Universal Protein Extraction kit were obtained from Sigma-Aldrich (St. Louis, MO, USA). RPMI-1640 medium, SYBR GREENER qPCR UNIVERSAL and primers sequences were obtained from Invitrogen, USA. DEVD-AMC (AspGlu-Val-Asp-7-amino-4-methylcoumarin) and IETDAMC (Ile-Glu-Thr-Asp-amino-4-methylcoumarin) were obtained from Biosource, USA. IPG gel strips were purchased from GE Healthcare, Uppsala, Sweden. Trypsin was obtained from Promega Madison, WI, USA. Mouse monoclonal antibodies to cytochrome c, Bax and Bcl-2 and rabbit polyclonal antibody to $\mathrm{Bcl}-\mathrm{xL}$, and horseradish peroxidase (HRP) conjugated secondary antibodies were purchased from Abcam, Cambridge, UK. SuperSignal West Pico Chemiluminecent Substrate was obtained from Pierce, Rockford, IL, USA. Complete mini protease inhibitor cocktail was obtained from Roche, Basel, Switzerland. Fluo3-AM and Rhod2-AM were obtained from Molecular Probes, Eugene, OR, USA. RNA extraction kit was obtained from Pharmacia Bioscience, Uppsala, Sweden. RevertAid ${ }^{\text {tw }}$ First Strand cDNA Synthesis kit was obtained from MBI Fermentas, Germany.

\section{Cell culture}

Human promyelocytic leukemic HL-60 and human promonocytic U937 cells were gifts from Dr. Sukhathida Ubol and Dr. Watchara Kasinroek. The cells were cultured in 10\% fetal bovine serum in RPMI-1640 medium supplemented with penicillin G (100 units/ml) and

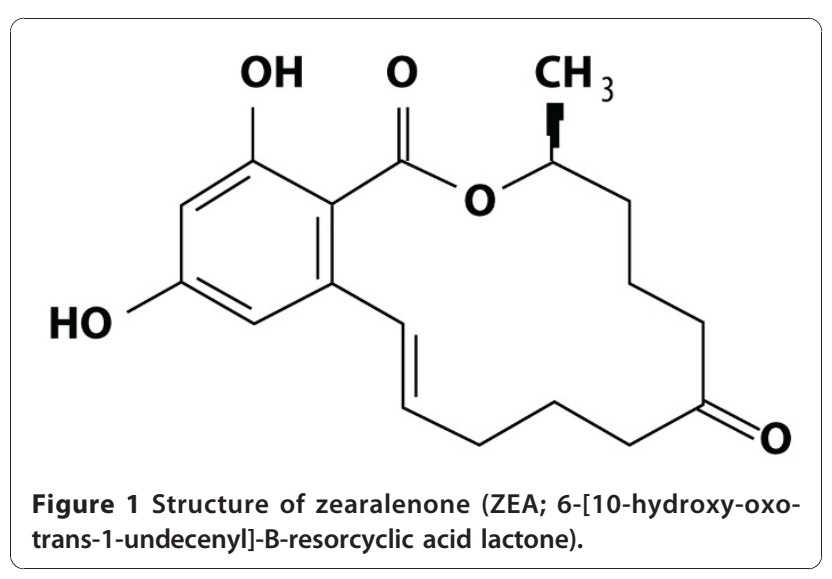


streptomycin $(100 \mu \mathrm{g} / \mathrm{ml})$ at $37^{\circ} \mathrm{C}$ in a humidified atmosphere containing $5 \% \mathrm{CO}_{2}$. The human leukemic cells $\left(1 \times 10^{6}\right)$ were treated with ZEA at indicated concentration and duration. ZEA was dissolved in DMSO as a vehicle and the maximal volume used was not exceeded $10 \mu \mathrm{l} / \mathrm{ml}$ of media.

The blood was obtained from adult volunteers with IRB approval. Peripheral blood mononuclear cells (PBMCs) were isolated from heparinized blood by density gradient centrifugation using lymphoprep according to standard protocols. Cells were cultured in RPMI1640 medium supplemented with $10 \%$ heat-inactivated fetal bovine serum, $2 \mathrm{mM}$ glutamine, $100 \mathrm{U} / \mathrm{ml}$ penicillin and $100 \mu \mathrm{g} / \mathrm{ml}$ streptomycin. PBMCs $\left(3 \times 10^{6}\right)$ were treated with ZEA at indicated concentration and duration.

\section{Cytotoxicity test}

Following ZEA treatment, cell viability was assessed by MTT (3-(4,5-dimethyl)-2,5-diphenyl tetrazolium bromide) assay [26]. This method is based on the ability of viable cells to reduce MTT and form a blue formazan product. MTT solution (sterile stock solution of $5 \mathrm{mg} / \mathrm{ml}$ ) was added to cell suspension at a final concentration of $100 \mu \mathrm{g} / \mathrm{ml}$ and the solution incubated for $4 \mathrm{~h}$ at $37^{\circ} \mathrm{C}$ in a humidified $5 \% \mathrm{CO}_{2}$ atmosphere. The medium was then removed and cells were treated with DMSO for $30 \mathrm{~min}$. The optical density of the cell lysate was measured at $540 \mathrm{~nm}$ with reference wavelength of $630 \mathrm{~nm}$ using microtiter plate reader (Biotek, USA). Number of viable cells was calculated from untreated cells, and the data were expressed as percent cell viability.

\section{Determination of mitochondrial transmembrane potential and ROS production}

For measurement of mitochondrial membrane potential and intracellular ROS, either $40 \mathrm{nM}$ 3,3'-dihexyloxacarbocyanine iodide (for mitochondrial transmembrane potential determination) or $5 \mu \mathrm{M}$ 2',7'-dichlorofluorescein diacetate (for ROS detection) were added for $15 \mathrm{~min}$ at $37^{\circ} \mathrm{C}$ and the cells are then subjected to flow cytometry.

For flow cytometric assessment of DNA fragmentation and cell cycle distribution, $1 \times 10^{6}$ cells were harvested and re-suspended in a solution containing PI $(50 \mu \mathrm{g} / \mathrm{ml})$, $0.1 \%$ Triton X-100 and $0.1 \%$ sodium citrate in PBS. Cells then were analyzed in a FACScan equipped with a $488 \mathrm{~nm}$ argon laser using CellQuest software (BectonDickinson, USA). Data were depicted as histograms and the percentage of cells displaying hypodiploid DNA content was indicated. Percentage of cells in each phase was also evaluated to determine the existence of cell cycle arrest.

\section{Assay of caspase- 3 and caspase- 8 activity}

Cleavage of the fluorogenic peptide substrates DEVDAMC and IETD-AMC, indicative of caspase-3-like and caspase-8-like enzyme activity, was estimated. Cell lysates $\left(1 \times 10^{6}\right.$ cells $)$ and substrate $(50 \mu \mathrm{M})$ were combined in a standard reaction buffer and added to a 96-well plate. Enzyme-catalyzed release of AMC was measured by a fluorescence plate reader (Bio-tek, USA) using $355 \mathrm{~nm}$ excitation and $460 \mathrm{~nm}$ emission wavelengths.

\section{Two-dimensional polyacrylamide gel-electrophoresis (2-D PAGE)}

U937 cells, treated and untreated with $20 \mu \mathrm{M}$ ZEA for 4 and $24 \mathrm{~h}$ were harvested and washed twice and the cell precipitates were used further. Albumin was first removed using ProteoExtract Albumin/Removal kit. The amount of protein loaded in 2-D PAGE was $200 \mu \mathrm{g} / \mathrm{gel}$. 2-D PAGE was performed using the immobiline/polyacrylamide system. Samples were applied by overnight ingel rehydration of $70 \mathrm{~mm}$ nonlinear $\mathrm{pH} 3-10$ IPG gel strips. The first dimension (IEF) was performed at 6500 Vh for $3.5 \mathrm{~h}$, using a Pharmacia LKB Multiphor II system. IPG strips were equilibrated with buffer in two steps. The first step employed $50 \mathrm{mM}$ Tris- $\mathrm{HCl}$ buffer, $\mathrm{pH}$ 6.8, $6 \mathrm{M}$ urea, 30\% glycerol, 1\% SDS, and 1\% DTT, while $2.5 \%$ iodoacetamide replaced DTT in the second step. Then IPG strips were applied to the seconddimension $12.5 \% \mathrm{~T}$ SDS polyacrylamide gels $(100 \mathrm{~mm} \times$ $105 \mathrm{~mm} \times 1.5 \mathrm{~mm}$ ). Electrophoresis was performed in a Hoefer system at $20 \mathrm{~mA}$ for $2.5 \mathrm{~h}$ at room temperature. After electrophoresis, proteins were visualized by CBR250 staining.

\section{PAGE of plasma membrane proteins}

ProteoPrep Universal Protein Extraction kit was used to isolate membrane and cytosolic proteins from HL-60 cell line. The cytoplasmic extraction reagent was added to the cell pellet and the sample was sonicated at $4^{\circ} \mathrm{C}$ and centrifuged at $14,000 \times g$ for $45 \mathrm{~min}$. The supernatant was collected. The same reagent was added to the remaining pellet, followed by sonication and centrifugation, and the resulting supernatant was pooled with that obtained earlier. The pooled supernatant was dried using Speed Vac. The dried sample was resuspended in the soluble protein resuspension reagent (Sup1).

The precipitate was resuspended in cellular and organelle membrane solubilizing reagent. The sample was centrifuged at $14,000 \times g$ for $45 \mathrm{~min}$ at $15^{\circ} \mathrm{C}$. The supernatant was collected as Sup2. Sup1 and 2 were treated with $5 \mathrm{mM}$ tributylphosphine (TBP) (reduction) for $1 \mathrm{~h}$ at room temperature, then $15 \mathrm{mM}$ iodoacetamide (alkylation) was added and the reaction mixture was incubated for $1.5 \mathrm{~h}$. The reaction was stopped by adding 
TBP and incubated for $15 \mathrm{~min}$. The sample was centrifuged at 20,000 $\times g$ for $5 \mathrm{~min}$ at room temperature and the clear supernatant was collected. The concentrations of proteins in Sup1 and Sup2 were measured using the Bradford method. Samples were prepared for 2-D PAGE by adding ampholine and solubilizing reagent to adjust the volume.

2-D PAGE was performed using the immobiline/polyacrylamide system. Samples were applied by overnight in-gel rehydration of $70 \mathrm{~mm}$ nonlinear pH 3-10 IPG gel strips. The first dimension electrophoresis (IEF) was performed as described for U937 cells.

\section{Tryptic in-gel digestion of protein spots}

Differential expression of proteomic profiles in treated and untreated cell lines were compared. Spots of interest were excised and transferred to $1.5 \mathrm{ml}$ tubes. A $50 \mu \mathrm{l}$ aliquot of $0.1 \mathrm{M} \mathrm{NH}_{4} \mathrm{HCO}_{3}$ in $50 \%$ acetonitrile was added, and the gel was incubated for $20 \mathrm{~min}$ at $30^{\circ} \mathrm{C}$. The solvent was discarded and the gel particles were dried completely. Reduction and alkylation was performed by swelling the gel pieces in $50 \mu \mathrm{l}$ buffer solution $\left(0.1 \mathrm{M} \mathrm{NH}_{4} \mathrm{HCO}_{3}, 10 \mathrm{mM} \mathrm{DTT}\right.$, and $1 \mathrm{mM}$ EDTA) and incubating at $60^{\circ} \mathrm{C}$ for $45 \mathrm{~min}$. Then the excess liquid was removed and quickly replaced by the same volume of freshly prepared $100 \mathrm{mM}$ iodoacetamide in $0.1 \mathrm{M} \mathrm{NH}_{4} \mathrm{HCO}_{3}$ solution. The gel suspension was incubated at room temperature in the dark for $30 \mathrm{~min}$ and iodoacetamide solution removed. Each gel piece was washed with $50 \%$ acetonitrile in water 3 times for $10 \mathrm{~min}$, and completely dried. A $50 \mu \mathrm{l}$ aliquot of digestion buffer $(0.05 \mathrm{M}$ Tris $\mathrm{HCl}, 10 \%$ acetonitrile, $\left.1 \mathrm{mM} \mathrm{CaCl}_{2}, \mathrm{pH} 8.5\right)$ and $1 \mu \mathrm{l}$ aliquot of trypsin $(1 \mathrm{mg}$ trypsin in $10 \mu \mathrm{l} 1 \%$ acetic acid) were added to the gel pieces. The mixtures were incubated at $37^{\circ} \mathrm{C}$ overnight. The digestion buffer was removed and saved. The gel pieces were then extracted by adding $60 \mu \mathrm{l}$ of $2 \%$ freshly prepared trifluoroacetic acid and incubating for $30 \mathrm{~min}$ at $60^{\circ} \mathrm{C}$. The extract and saved digestion buffer were pooled and dried. Digested peptides were dissolved in $6 \mu \mathrm{l}$ of $0.1 \%$ formic acid for MS/MS injection.

\section{Protein identification by LC-MS/MS}

LC-MS/MS analyses were carried out using a capillary LC system (Waters, UK) coupled to a Q-TOF mass spectrometer (Micromass, Manchester, UK) equipped with a Z-spray ion-source working in the nanoelectrospray mode. Glu-fibrinopeptide was used to calibrate the instrument in MS/MS mode. Tryptic peptides were concentrated and desalted on a $75 \mu \mathrm{m}$ ID $\times 150 \mathrm{~mm} \mathrm{C18}$ PepMap column (LC Packings, Amsterdam, The Netherlands). Eluent A and B was $0.1 \%$ formic acid in $97 \%$ water, $3 \%$ acetonitrile and $0.1 \%$ formic acid in $97 \%$ acetonitrile respectively. Six $\mu$ l of sample were injected into the nanoLC system, and separation was performed using the following gradient: 0 min $7 \%$ eluent B, 35 min 50\% B, 45 min $80 \%$ B, 49 min 80\% B, 50 min 7\% B, 60 min $7 \%$ B. Database search was performed with ProteinLynx screening SWISS-PROT and NCBI. For proteins that were difficult to find, Mascot search tool available on the Matrix Science site screening NCBInr was used.

\section{Gel scanning and image analysis}

Stained gels were scanned using an ImageScanner II (GE Healthcare, Uppsala, Sweden) and ImageMaster ${ }^{\mathrm{mm}}$ (GE Healthcare, Uppsala, Sweden) was used for computer analysis.

\section{Flow cytometric analysis of cell surface calreticulin}

HL-60 cells were plated in 24-well plates and incubated for the indicated time. Cells were harvested, washed twice with PBS and incubated for 30 min with primary antibody, diluted in cold blocking buffer ( $2 \%$ FBS in PBS), followed by washing and incubation for $30 \mathrm{~min}$ with the FITC-conjugated monoclonal secondary antibody diluted 1:500 in blocking buffer. Each sample was then analyzed by FACScan (Becton Dickinson, USA) to identify cell surface calreticulin. Isotype matched IgG antibodies were used as control, and the fluorescence intensity of stained cells was gated on PI-negative cells.

\section{Western blot analysis}

To obtain a cytosolic-rich fraction, ZEA-treated cells were harvested and washed once in ice cold PBS and incubated at $4^{\circ} \mathrm{C}$ for $10 \mathrm{~min}$ with ice-cold cell lysis buffer $(250 \mathrm{mM}$ sucrose, $70 \mathrm{mM} \mathrm{KCl}, 0.25 \%$ Triton X-100, $100 \mu \mathrm{M}$ PMSF, $1 \mathrm{mM}$ DTT in PBS with complete mini protease inhibitor cocktail). The cell suspension was centrifuged at $20,000 \times g$ for $20 \mathrm{~min}$. The supernatant was collected as the cytosolic-rich fraction. Protein concentration of the cytosolic-rich fraction was determined by the Bradford method. Cytosolic proteins $(50 \mu \mathrm{g})$ were separated by $17 \%$ SDS-PAGE and transferred onto nitrocellulose membranes. After treating with $5 \%$ non-fat milk in TBS containing $0.2 \%$ Tween-20 (blocking buffer), membranes were incubated with mouse monoclonal antibodies to cytochrome c, Bax and Bcl-2 and rabbit polyclonal antibody to $\mathrm{Bcl}-\mathrm{xL}$. For detection, appropriate horseradish peroxidase (HRP) conjugated secondary antibodies were used at 1:20,000 dilution. Protein bands were visualized on X-ray film with SuperSignal West Pico Chemiluminecent Substrate.

FACS analysis for cytosolic and mitochondrial $\mathrm{Ca}^{2+}$ levels Cytosolic $\mathrm{Ca}^{2+}$ levels were determined using the fluorescence dye $1 \mu \mathrm{M}$ Fluo3-AM in FITC setting. Mitochondrial $\mathrm{Ca}^{2+}$ levels were determined using the fluorescent dye $250 \mathrm{nM}$ Rhod2-AM in PE setting. After treatment 
with ZEA for $4 \mathrm{~h}$, cells were incubated with fluorescent dye for $15 \mathrm{~min}$ at $37^{\circ} \mathrm{C}$, and washed with PBS containing $10 \mathrm{mM}$ glucose and analyzed immediately by flow cytometry. In each analysis, 10,000 events were recorded and analyzed by FACScan (Becton Dickinson, USA).

\section{RNA extraction and gene expression analysis}

Real-time PCR was used to examine expression of endoplasmic reticulum stress genes, viz. calreticulin (CRT), glucose-regulated protein-78 (GRP78) and endoplasmic reticulum protein-29 (ERp29), in the human leukemic cell culture. RNA was isolated from HL-60 cell culture using RNA extraction kit following the manufacturer's protocol. Total RNA $(1 \mu \mathrm{g})$ was converted to cDNA using RevertAid ${ }^{\mathrm{ma}}$ First Strand cDNA Synthesis Kit. For determination of ER stress gene expression, SYBR Green detection was used and the values were normalized using glyceraldehyde-3-phosphate dehydrogenase (GAPDH). Real-time quantitative polymerase chain reaction (PCR) was performed in a DNA Engine (ABi 7500) using SYBR GREENER qPCR UNIVERSAL. Primers sequences are as in Table 1. Relative expression levels for each primer set were normalized to the expression of GAPDH by the $2^{-\triangle \mathrm{CT}}$ method [27].

\section{Statistical analysis}

Results were expressed as mean \pm SEM (standard error of mean). Statistical difference between control and treated group was determined by the one-way ANOVA (Kruskal Wallis analysis) at limit of $\mathrm{p}<0.05$ in triplicate of three independent experiments. For comparison between two groups, data were analyzed using Student's $t$-test.

\section{Results}

\section{Cell cytotoxicity with apoptotic induction}

Cell viability was evaluated in HL-60, U937 and PBMCs after incubation with ZEA for $24 \mathrm{~h}$ using MTT assay. ZEA was toxic to U937 and HL-60 cells with $\mathrm{IC}_{50}$ value

Table 1 Primer Sequences Used for Real-time Reverse Transcription Polymerase Chain Reaction.

\begin{tabular}{lll}
\hline Gene & Sequences $\left(\mathbf{5}^{\prime} \mathbf{3}^{\prime} \mathbf{\prime}\right)$ & $\begin{array}{l}\text { GenBank accession } \\
\text { number }\end{array}$ \\
\hline GRP78 & $\begin{array}{l}\text { Forward: } \\
\text { GCCTGTATTCTAGACCTGCC }\end{array}$ & NM_005347.3 \\
& Reverse: TTCATCTTGCCAGCCAGTTG & \\
\hline CRT & $\begin{array}{l}\text { Forward: } \\
\text { AAATGAGAAGAGCCCCGTTCTCCT }\end{array}$ & NM_004343.3 \\
& $\begin{array}{l}\text { Reverse: } \\
\text { AAGCCACAGGCCTGAGATTTCATCTG }\end{array}$ & \\
\hline ERp29 & $\begin{array}{l}\text { Forward: } \\
\text { CCTGAAGATCATGGGGAAGA }\end{array}$ & NM_001034025.1 \\
& Reverse: TTCTGGAAGGCAGTCAGGAT & \\
\hline GAPDH & $\begin{array}{l}\text { Forward: GAAGGTGAAGGTCGGAGTC } \\
\text { Reverse: GAAGATGGTGATGGGATTC }\end{array}$ & \\
\hline
\end{tabular}

of $5.1 \mu \mathrm{g} / \mathrm{ml}$ and $44 \mu \mathrm{g} / \mathrm{ml}$, respectively, but was less toxic to PBMCs, $\left(\mathrm{IC}_{50}\right.$ value $>80 \mu \mathrm{g} / \mathrm{ml}$ ) (Figure $2 \mathrm{~A}$ ). However, low concentrations of ZEA (5-20 $\mu \mathrm{g} / \mathrm{ml})$ had a proliferative effect on PBMCs. ZEA induced apoptotic death of HL-60 cells as evidenced by the changes in cell morphology (condensed nuclei and apoptotic bodies) (data not shown) and presence of cells with subdiploid DNA (Figure 2B). There was G1 arrest in HL-60 cells treated with $50 \mu \mathrm{g} / \mathrm{ml} \mathrm{ZEA} \mathrm{(Figure} \mathrm{2C)} \mathrm{and} \mathrm{in} \mathrm{U937}$ cells with $16 \mu \mathrm{g} / \mathrm{ml}$ (Figure 2D).

\section{Mitochondria involvement in ZEA-induced HL-60 and U937 cell apoptosis}

The reduction of mitochondrial transmembrane potential (MTP) accompanied by release of cytochrome c into cytosol is often associated with apoptosis [28]. Treatment with ZEA resulted in an increase in percent cells with reduced MTP (Figure 3A and 3B) and cytosolic cytochrome $\mathrm{c}$ in a dose dependent manner in HL-60 (Figure 3C).

\section{Expression of Bax, Bcl-2 and $\mathrm{BCl}-\mathrm{xL}$ in ZEA-treated HL-60 cells}

The mitochondrial apoptotic signaling pathway involves Bax, a proapoptotic Bcl-2 family member, which induces permeabilization of the mitochondrial outer membrane allowing release of cytochrome c [29-31]. Bax expression in HL-60 cells was up regulated in time dependent manner (Figure 4A). Expression of anti-apoptotic Bcl-2 did not change, whereas that of anti-apoptotic Bcl-xL was down regulated time-dependently (Figure 4A and 4B).

\section{ROS production of ZEA on human leukemic cells}

Changes in MTP are considered to involve ROS production [32]. The ability of ZEA to generate ROS was investigated using a fluorescence sensitive probe (dichlorofluorescein diacetate), which detects peroxide radicals and various other active oxygen radicals $[33,34]$. ROS was produced in ZEA-treated HL-60 (Figure 5) indicating that the cause of apoptotic cell injury was via oxidative stress.

\section{Effect of ZEA on activities of caspase-3 and -8 in HL-60 and $U 937$ cells}

To address the role of activation of caspase activities in ZEA-induced HL-60 and U937 apoptosis, specific caspase substrates were used, namely DEVD-AMC (caspase-3 substrate) and IETD-AMC (caspase-8 substrate). ZEA induced in a dose-dependent manner activation of caspase- 3 activity but not that of caspase- 8 in HL-60 (Figure 6A) and U937 cells (Figure 6B).

\section{Protein expression in ZEA-treated U937 and HL-60 cells} The effects of ZEA on protein expression in U937 and HL-60 cells were explored by 2D-PAGE. In U937 cells 
A
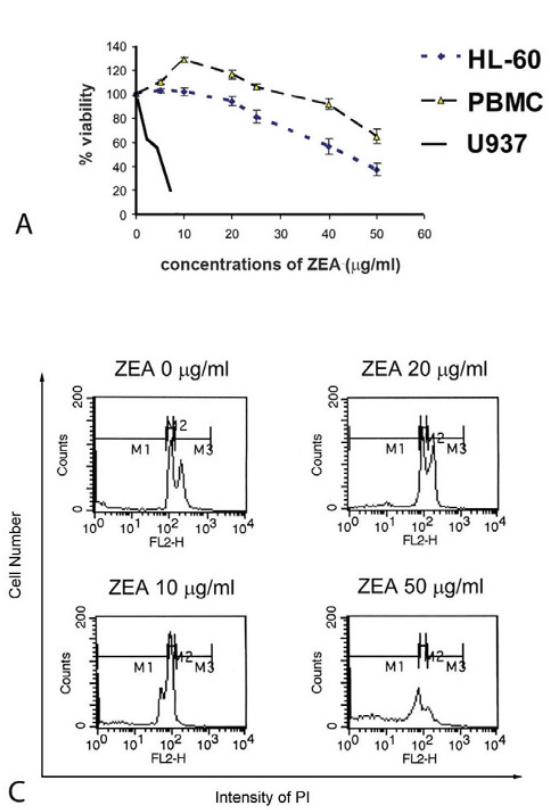

$\mathrm{HL}-60$

U937

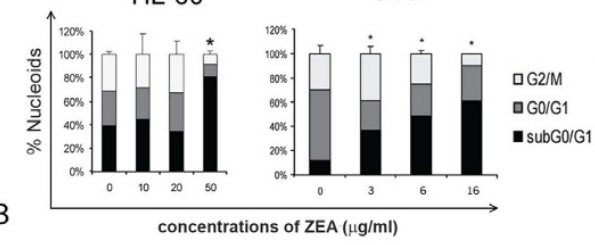

|
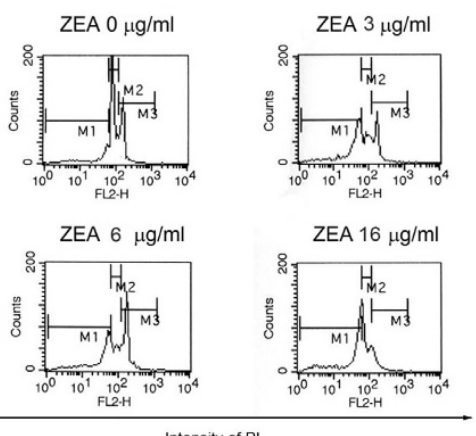

Figure 2 Effect of ZEA on cell cytotoxicity and apoptotic induction of human leukemic HL-60 and U937 cells. (A) Cell viability of HL-60, U937 and human peripheral blood mononuclear cells using MTT assay. (B) DNA cell cycle analysis of HL-60 and U937 cells treated with ZEA for 24 h. ${ }^{*} p<0.05$, compared with control cells. (C) and (D) Histograms of HL-60 and U937 cells treated with ZEA at indicated concentrations,

respectively. Cells were stained with PI and subjected to flow cytometer as described in Materials and methods. M1, subdiploid; M2, G1; M3, G2 M.
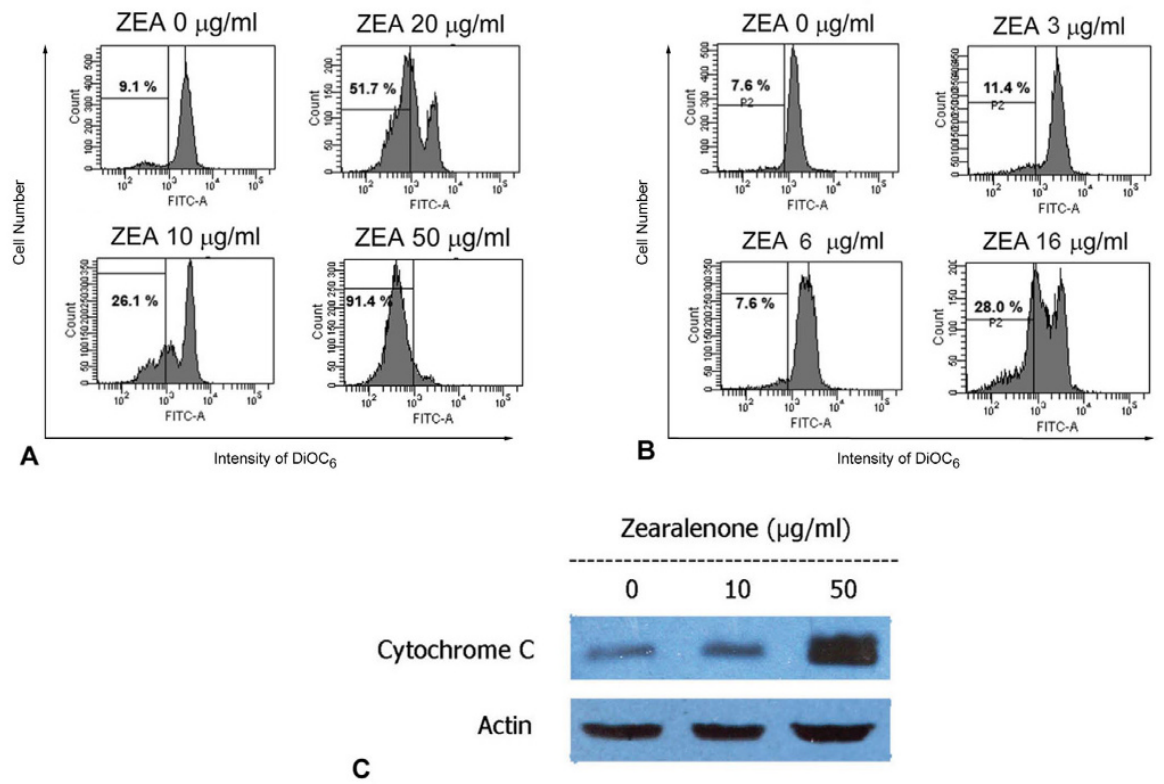

Figure 3 Mitochondria-mediated human leukemic cell apoptosis. Reduction of mitochondrial transmembrane potential of HL-60 (A) and U937 (B) cells treated with ZEA. Cells were stained with $40 \mathrm{nM} \mathrm{DiOC}_{6}$ for $15 \mathrm{~min}$ and then subjected to flow cytometry. Cells with decreased mitochondrial transmembrane potential are less stained with $\mathrm{DiOC}_{6}$. (C) Release of cytochrome $\mathrm{c}$ from mitochondria. $\mathrm{HL}-60$ cells were treated with ZEA $(10,50 \mu \mathrm{g} / \mathrm{ml})$ for $4 \mathrm{~h}$ and cytosolic cytochrome $\mathrm{c}$ was detected by Western blotting. Representative data from three independent experiments are shown. 


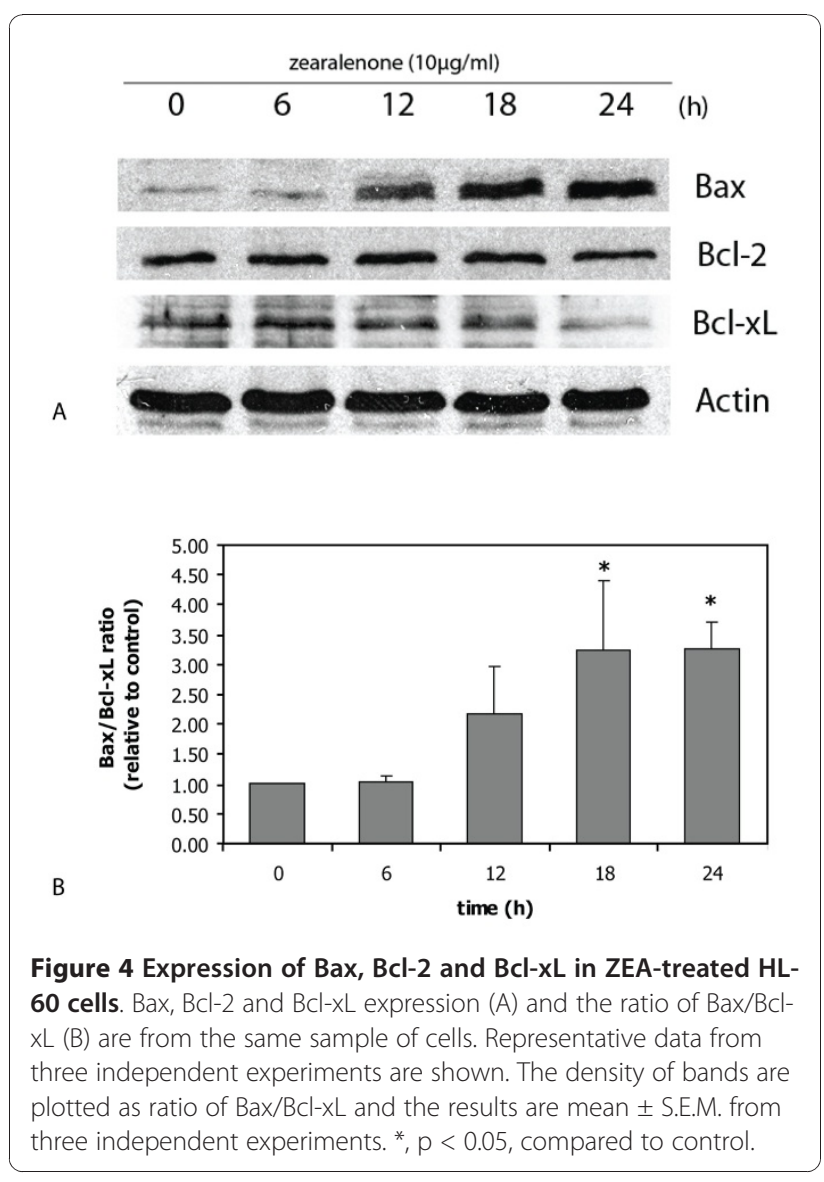

treated with ZEA for 4 and $24 \mathrm{~h}, 4$ spot differences were detected (Figure 7A), which subsequently were shown by LC-MS/MS to be fructose bisphosphate aldolase A, muscle type, lung cancer antigen NY LU 1 (increased in ZEA-treated cells at 4 and $24 \mathrm{~h}$, arrow 1 ), glyceraldehyde 3-phosphate dehydrogenase isozymes (GAPDH) (increased in treated cells at 4 and $24 \mathrm{~h}$, arrows 2 and 3 )

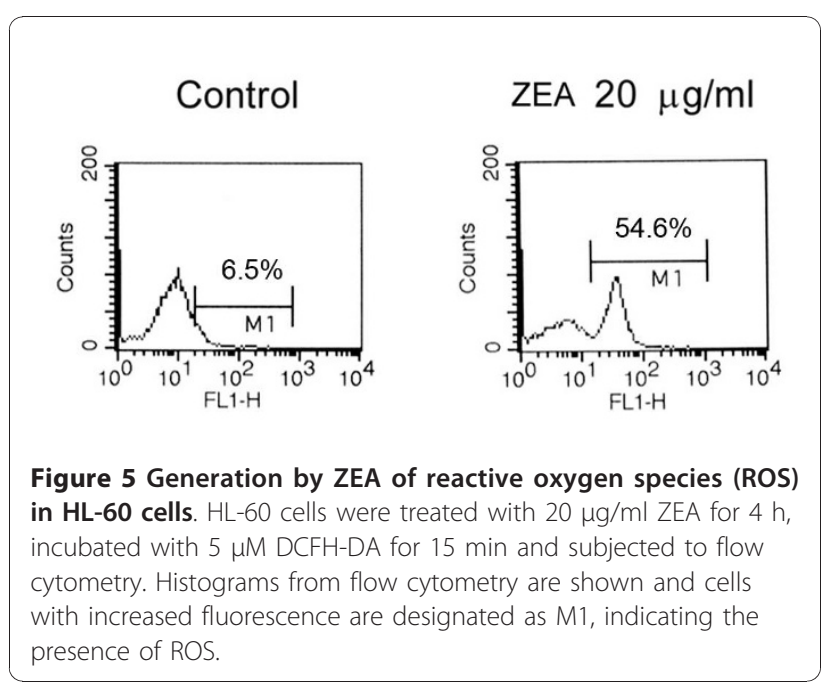

and deoxyuridine triphosphate nucleotidohydrolase mitochondrial precursor dUTP pyrophosphatase (increased in treated cells at $24 \mathrm{~h}$, arrow 4 ).

2D-PAGE revealed 22 proteins with different expression in the plasma membrane of HL-60 cells treated with ZEA for $24 \mathrm{~h}$ compared to control (Figure $7 \mathrm{~B}$ and Table 2). LC-MS/MS indicated that the up regulated proteins included $78 \mathrm{kDa}$ glucose-regulated protein or GRP78 (Figure 7B and Table 2, dot no. 3; 1.93 foldedincrease), calreticulin or CRT (dot no. 5; 2.39 foldedincrease), endoplasmic reticulum protein ERp29 (dot no. 21; 2.99 folded-increase), and apoptosis inducing factor (AIF) (dot no. 11; 2.18 folded-increase), whereas expression of heat shock protein 90 (HSP90), which plays a role in ER protein folding [35], was decreased (dot no. 2; 1.55 folded-decrease, Table 2). These results point to the presence of ER stress in ZEA-treated leukemic cells.

\section{ER stress gene expression at mRNA levels}

The results of 2-dimensional gel electrophoresis led us to examine the ER stress gene expression at mRNA levels of three genes (GRP78,CRT and ERp29), which were increased in 2-D PAGE (Table 2), employing real-time RT-PCR. GRP78 mRNA had a tendency to be up regulated in a time response manner whereas CRT mRNA was down regulated in a time response pattern as shown in Figure 8. However, ERp29 mRNA expression prominently increased 3.8 folds compared to control (Figure 8), which supported the rising amount of ERp29 protein in 2-D (2.99 folds as in Table 2).

\section{Cytosolic and mitochondrial $\mathrm{Ca}^{2+}$ status in ZEA-treated leukemic cells}

Increases in cytosolic and mitochondrial $\mathrm{Ca}^{2+}$ levels have been found in ER stressed cells [36]. As indicated above, apoptosis of leukemic cells induced by ZEA also involved ER stress, $\mathrm{Ca}^{2+}$ levels in both mitochondria and cytosol were measured. FACS analysis histograms of Fluo3-AM-stained (Figure 9A) and Rhod2-stained (Figure 9B) HL-60 cells treated with 10 and $20 \mu \mathrm{g} / \mathrm{ml}$ ZEA revealed increased $\mathrm{Ca}^{2+}$ levels in both cytosolic and mitochondrial compartments.

\section{Effect of ZEA treatment on calreticulin exposure on cell surface}

Reduction of ER $\mathrm{Ca}^{2+}$ level (ER stress) favors cell surface exposure of calreticulin [37]. Exposure for $30 \mathrm{~min}$ of HL-60 cells to ZEA $(10,20$ and $50 \mu \mathrm{g} / \mathrm{ml})$ did not produce an increase in the presence of calreticulin on the cell surface as assessed by FACS (Figure 10).

\section{Discussion}

ZEA is a non-steroidal estrogenic mycotoxin produced as a secondary metabolite by several fungi of the genus 
HL-60

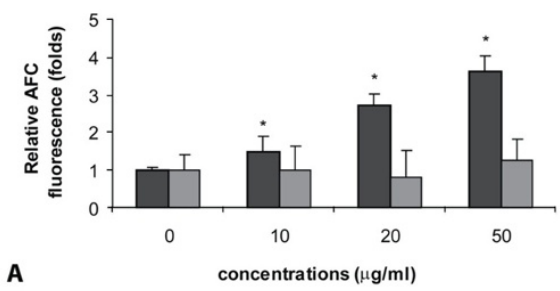

U937

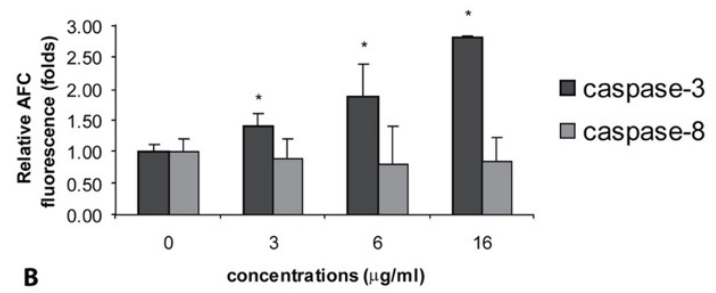

Figure 6 Effect of zearalenone (ZEA) on activation of caspase-3 and caspase-8. Activity of caspase-3 and caspase-8 of HL-60 (A) and U937 (B) cells treated for $24 \mathrm{~h}$ with various concentrations of ZEA were measured using specific substrate analogs as described in Materials and methods. Data represent mean values \pm S.E.M. from three independent experiments. ${ }^{*}, p<0.05$, compared to control.

a.

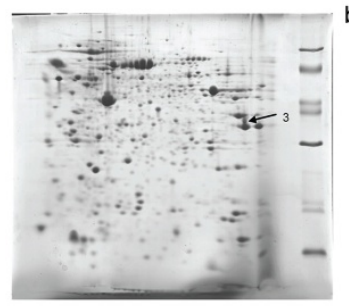

U937 Control, 4h (column to remove albumin)

c.

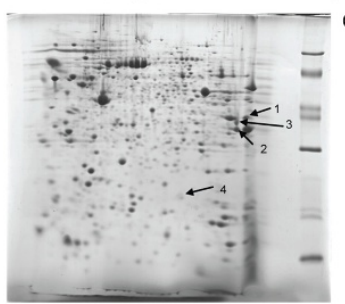

U937 $+6 \mu \mathrm{g} / \mathrm{ml}$ Zearalenone, $4 \mathrm{~h}$

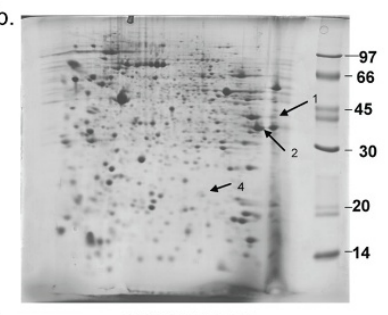

U937 Control, 24h

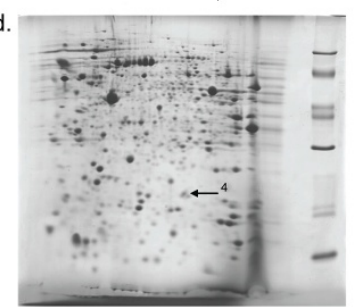

U937 $+6 \mu \mathrm{g} / \mathrm{ml}$ Zearalenone, $24 \mathrm{~h}$

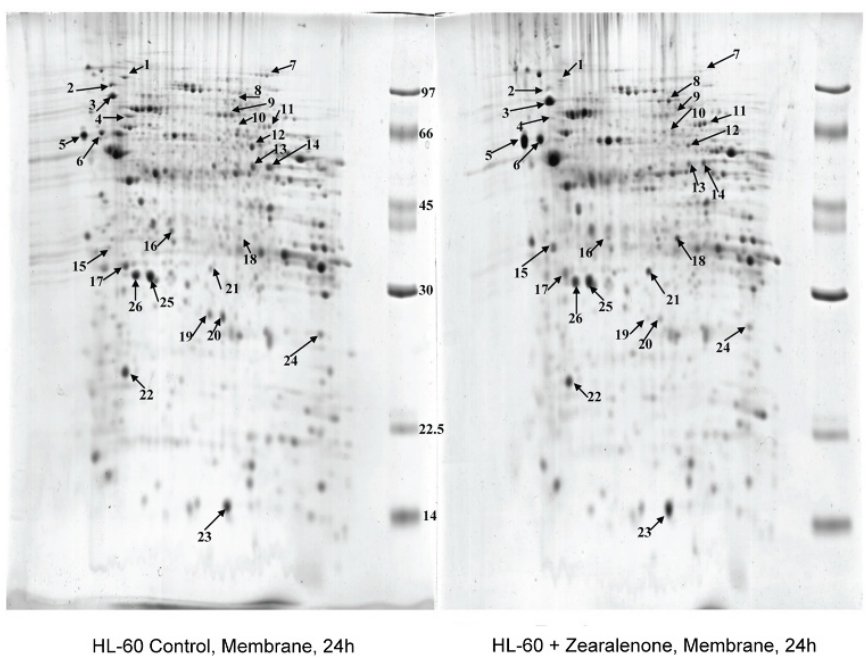

Figure 7 Two-dimensional polyacrylamide gel-electrophoresis pattern of U937 and HL-60 cells. (A) U937 cells cultured for 4 and $24 \mathrm{~h}$ in the presence or absence of ZEA. (a) control $4 \mathrm{~h}$ cells, (b) control $24 \mathrm{~h}$ cells, (c) cells treated with $6 \mu \mathrm{g} / \mathrm{ml}$ ZEA for $4 \mathrm{~h}$, (d) cells treated with 6 $\mu \mathrm{g} / \mathrm{ml}$ ZEA for $24 \mathrm{~h}$. (Arrow 1) fructose bisphosphate aldolase A, muscle type, lung cancer antigen NY LU1, (arrow 2 and 3) glyceraldehyde 3phosphate dehydrogenase, (arrow 4) deoxyuridine triphosphate nucleotidohydrolase, mitochondrial precursor. (B) HL-60 cell cultured for $24 \mathrm{~h}$ with (right panel) and without ZEA (left panel). There are 22 protein dots of different expression in plasma membrane. The list of proteins identified by LC/MS/MS is shown in Table 1. 
Table 2 Identified Plasma Membrane Protein Spots in 24 h ZEA-treated HL-60 Cells by LC/MS/MS

\begin{tabular}{|c|c|c|c|c|c|c|c|}
\hline $\begin{array}{l}\text { Spot } \\
\text { no. }\end{array}$ & $\begin{array}{l}\text { Protein Name } \\
\text { (s) }\end{array}$ & Description & $\begin{array}{c}\mathrm{MW} / \\
\mathrm{pl}\end{array}$ & $\begin{array}{l}\text { Peptide } \\
\text { match }\end{array}$ & $\begin{array}{c}\% \\
\text { Coverage }\end{array}$ & Sequence & $\begin{array}{l}\text { *Expression } \\
\text { in treated } \\
\text { cells (folds) }\end{array}$ \\
\hline 1 & TERA_HUMAN & $\begin{array}{l}\text { Transitional endoplasmic } \\
\text { reticulum ATPase }\end{array}$ & $\begin{array}{c}89.3 / \\
5.18\end{array}$ & - & - & - & -1.99 \\
\hline \multirow[t]{3}{*}{2} & GFAP_HUMAN & $\begin{array}{l}\text { Glial fibrillary acidic } \\
\text { protein }\end{array}$ & $\begin{array}{l}49.8 / \\
5.25\end{array}$ & 1 & 2.55 & (K)LALDIEIATYR(K) & -1.55 \\
\hline & K2C8_HUMAN & $\begin{array}{l}\text { Keratin, type II } \\
\text { cytoskeletal } 8\end{array}$ & $\begin{array}{l}53.7 / \\
5.34\end{array}$ & 1 & 2.28 & & \\
\hline & HS90A_HUMAN & $\begin{array}{l}\text { Heat shock protein HSP } \\
\text { 90-alpha }\end{array}$ & $\begin{array}{l}83.2 / \\
4.97\end{array}$ & 7 & 10.00 & $\begin{array}{l}\text { K.IDIIPNPQER.T } \\
\text { K.EDQTEYLEER.R } \\
\text { K.HFSVEGQLEFR.A } \\
\text { R.RAPFDLFENK.K } \\
\text { R.GWDSEDLPLNISR.E } \\
\text { K.FYEAFSK.N } \\
\text { K.EGLELPEDEEEK.K } \\
\end{array}$ & \\
\hline 3 & GRP78_HUMAN & $\begin{array}{l}78 \mathrm{kDa} \text { glucose-regulated } \\
\text { protein precursor (GRP } \\
78 \text { ) }\end{array}$ & $\begin{array}{l}72.3 / \\
5.10\end{array}$ & - & - & - & 1.93 \\
\hline 4 & PLSL_HUMAN & $\begin{array}{l}\text { L-plastin, Lymphocyte } \\
\text { cytosolic protein } 1\end{array}$ & $\begin{array}{l}70.2 / \\
5.02\end{array}$ & 11 & 22.01 & $\begin{array}{l}\text { (K)AACLPLPGYR(V) } \\
\text { (K)IGLFADIELSR(N) } \\
\text { (R)NEALIALLR(E) } \\
\text { (K)LSPEELLLR(W) } \\
\text { (K)AYYHLLEQVAPK(G) } \\
\text { (R)QFVTATDWR(G) } \\
\text { (K)LNLAFIANLFNR(Y) } \\
\text { (R)VNHLYSDLSDALVIFQLYEK(I) } \\
\text { (K)FSLVGIGGQDLNEGNR(T) } \\
\text { (R)YTLNILEEIGGGQK(V) } \\
\text { (K)VNDDIIVNWVNETLR(E) }\end{array}$ & -3.1 \\
\hline 5 & CALR_HUMAN & Calreticulin precursor & $\begin{array}{l}60.6 / \\
4.37 \\
\end{array}$ & - & - & - & 2.39 \\
\hline 6 & PDIA1_HUMAN & $\begin{array}{l}\text { Protein disulfide } \\
\text { isomerase precursor }\end{array}$ & $\begin{array}{l}51.1 / \\
4.78\end{array}$ & - & - & - & 2.86 \\
\hline 7 & EF2_HUMAN & Elongation factor 2 & $\begin{array}{l}95.1 / \\
6.78\end{array}$ & - & - & - & -2.87 \\
\hline 8 & gi|28317 & $\begin{array}{l}\text { unnamed protein } \\
\text { product }\end{array}$ & $\begin{array}{l}59.5 / \\
5.17\end{array}$ & 3 & 6.00 & $\begin{array}{l}\text { R.ALEESNYELEGK.I } \\
\text { R.QSVEADINGLR.R } \\
\text { R.NVQALEIELQSQLALK.Q }\end{array}$ & 2.26 \\
\hline \multirow[t]{2}{*}{9} & DHSA_HUMAN & $\begin{array}{l}\text { Succinate dehydrogenase } \\
\text { [ubiquinone] flavoprotein } \\
\text { subunit, mitochondrial }\end{array}$ & $\begin{array}{l}72.6 / \\
7.04\end{array}$ & 4 & 8.43 & $\begin{array}{l}\text { (R)AAFGLSEAGFNTACVTK(L) } \\
\text { (R)GVIALCIEDGSIHR(I) } \\
\text { (K)NTWATGGYGR(T) } \\
\text { (R)LGANSLLDLWFGR(A) }\end{array}$ & -1.29 \\
\hline & TCPG_HUMAN & $\begin{array}{l}\text { T-complex protein } 1 \\
\text { subunit gamma }\end{array}$ & $\begin{array}{l}60.5 / \\
6.06\end{array}$ & 1 & 2.02 & (K)TAVETAVLLLR(I) & \\
\hline \multirow[t]{4}{*}{10} & SERA_HUMAN & $\begin{array}{l}\text { D-3-phosphoglycerate } \\
\text { dehydrogenase }\end{array}$ & $\begin{array}{l}56.6 / \\
6.28\end{array}$ & 1 & 2.44 & (K)GTIQVITQGTSLK(N) & -1.34 \\
\hline & TCPZ_HUMAN & $\begin{array}{l}\text { T-complex protein } 1 \\
\text { subunit zeta }\end{array}$ & $\begin{array}{l}58.0 / \\
6.22 \\
\end{array}$ & 1 & 2.26 & (K)GIDPFSLDALSK(E) & \\
\hline & gi|4502643 & $\begin{array}{l}\text { chaperonin containing } \\
\text { TCP1, subunit } 6 \mathrm{~A} \\
\text { isoform a }\end{array}$ & $\begin{array}{l}58.0 / \\
6.23\end{array}$ & 7 & 15.00 & $\begin{array}{l}\text { R.AQAALAVNISAAR.G } \\
\text { K.QADLYISEGLHPR.I } \\
\text { R.IITEGFEAAK.E } \\
\text { K.ALQFLEEVK.V } \\
\text { K.SETDTSLIR.G } \\
\text { K.GIDPFSLDALSK.E } \\
\text { K.VLAQNSGFDLQETLVK.I }\end{array}$ & \\
\hline & gi|1002923 & coronin-like protein & $\begin{array}{l}51.0 / \\
6.12\end{array}$ & 7 & 15.00 & $\begin{array}{l}\text { R.HVFGQPAK.A } \\
\text { R.EPWTLEGHTK.R } \\
\text { R.AVFVSEGK.I } \\
\text { K.ILTTGFSR.M } \\
\text { R.DAGPLLISLK.D } \\
\text { R.AAPEASGTPSSDAVSR.L } \\
\text { K.LQATVQELQK.R }\end{array}$ & \\
\hline 11 & 119623333 & $\begin{array}{l}\text { apoptosis inducing factor } \\
\text { like isoform CRA d Homo } \\
\text { sapiens }\end{array}$ & $\begin{array}{l}63.7 / \\
10.23\end{array}$ & 1 & 1.21 & (R)LLSATSR(T) & 2.18 \\
\hline
\end{tabular}


Table 2 Identified Plasma Membrane Protein Spots in 24 h ZEA-treated HL-60 Cells by LC/MS/MS (Continued)

\begin{tabular}{|c|c|c|c|c|c|c|c|}
\hline & RN112_HUMAN & RING finger protein 112 & $\begin{array}{c}68.3 / \\
8.45\end{array}$ & 1 & 1.11 & (R)LSGRYPK(V) & \\
\hline & gi|4557014 & catalase [Homo sapiens] & $\begin{array}{c}59.7 / \\
6.90\end{array}$ & 12 & 28.00 & $\begin{array}{l}\text { K.ADVLTTGAGNPVGDK.L } \\
\text { K.LNVITVGPR.G } \\
\text { K.GAGAFGYFEVTHDITK.Y } \\
\text { R.FR.DPILFPSFIHSQK.R } \\
\text { STVAGESGSADTVR.D } \\
\text { K.NLSVEDAAR.L } \\
\text { R.LSQEDPDYGIR.D } \\
\text { R.DLFNAIATGK.Y } \\
\text { R.LFAYPDTHR.H } \\
\text { K.DAQIFIQK.K } \\
\text { K.NFTEVHPDYGSHIQALLDK.Y } \\
\text { K.NAIHTFVQSGSHLAAR.E }\end{array}$ & \\
\hline & gi|28317 & $\begin{array}{l}\text { unnamed protein } \\
\text { product }\end{array}$ & $\begin{array}{c}59.5 / \\
5.17\end{array}$ & 7 & 14.00 & $\begin{array}{l}\text { R.ALEESNYELEGK.I } \\
\text { K.YENEVALR.Q } \\
\text { R.QSVEADINGLR.R } \\
\text { K.ADLEMQIESLTEELAYLK.K } \\
\text { R.NVQALEIELQSQLALK.Q } \\
\text { K.QSLEASLAETEGR.Y } \\
\text { R.LENEIQTYR.S }\end{array}$ & \\
\hline \multirow[t]{4}{*}{12} & SAM50_HUMAN & $\begin{array}{l}\text { Sorting and assembly } \\
\text { machinery component } \\
50 \text { homolog }\end{array}$ & $\begin{array}{l}51.9 / \\
6.46\end{array}$ & 5 & 14.50 & $\begin{array}{l}\text { (K)VNQELAGYTGGDVSFIK(E) } \\
\text { (K)EDFELQLNK(Q) } \\
\text { (R)THFFLNAGNLCNLNYGEGPK(A) } \\
\text { (R)WSYGAGIVLR(L) } \\
\text { (R)ICDGVQFGAGIR(F) }\end{array}$ & -1.98 \\
\hline & gi|7022134 & $\begin{array}{l}\text { unnamed protein } \\
\text { product }\end{array}$ & $\begin{array}{l}51.9 / \\
6.62\end{array}$ & 9 & 20.00 & $\begin{array}{l}\text { K.DWWQHVHFDGLGR.T } \\
\text { K.VTFQFSYGTK.E } \\
\text { R.NFSVNLYK.V } \\
\text { K.VTGQFPWSSLR.E } \\
\text { K.WEGWWR.E } \\
\text { K.VNQELAGYTGGDVSFIK.E } \\
\text { K.EDFELQLNK.Q } \\
\text { R.FYLGGPTSVR.G } \\
\text { R.WSYGAGIVLR.L }\end{array}$ & \\
\hline & gi|4929571 & CGl-51 protein & $\begin{array}{l}52.1 / \\
6.85\end{array}$ & 10 & 26.00 & $\begin{array}{l}\text { K.DWWQHVHFDGLGR.T } \\
\text { K.VTFQFSYGTK.E } \\
\text { R.NFSVNLYK.V } \\
\text { K.VTGQFPWSSLR.E } \\
\text { K.WEGWWR.E } \\
\text { K.VNQELAGYTGGDVSFIK.E } \\
\text { K.EDFELQLNK.Q } \\
\text { K. } \\
\text { QLIFDSVFSASFWGGMLVPIGDKPSSIADRFYLGGPTSIR. } \\
\text { G } \\
\text { R.FYLGGPTSIR.G } \\
\text { R.WSYGAGIVLR.L }\end{array}$ & \\
\hline & $\overline{\text { ANX11_HUMAN }}$ & Annexin A11 & $\begin{array}{l}54.3 / \\
7.53\end{array}$ & 5 & 11.00 & $\begin{array}{l}\text { R.GTITDAPGFDPLR.D } \\
\text { K.TPVLFDIYEIK.E } \\
\text { R.LLISLSQGNR.D } \\
\text { R.SETDLLDIR.S } \\
\text { K.SLYHDISGDTSGDYR.K }\end{array}$ & \\
\hline 13,14 & ENOA_HUMAN & Alpha-enolase & $\begin{array}{l}47.0 / \\
7.54\end{array}$ & - & - & - & $\begin{array}{l}-1.57 \\
-1.88\end{array}$ \\
\hline \multirow[t]{4}{*}{15} & 119571303 & $\begin{array}{l}\text { spectrin domain with } \\
\text { coiled coils } 1 \text { isoform } \\
\text { CRA d Homo sapiens }\end{array}$ & $\begin{array}{c}28.9 / \\
4.97\end{array}$ & 1 & 4.20 & (R)LQIVSLASWAR(A) & 5.14 \\
\hline & ATPG_HUMAN & $\begin{array}{l}\text { ATP synthase subunit } \\
\text { gamma, mitochondrial }\end{array}$ & $\begin{array}{c}33.0 / \\
9.56\end{array}$ & 1 & 4.03 & (R)IYGLGSLALYEK(A) & \\
\hline & TPM3_HUMAN & $\begin{array}{l}\text { Tropomyosin alpha-3 } \\
\text { chain }\end{array}$ & $\begin{array}{l}32.8 / \\
4.49\end{array}$ & 1 & 2.82 & (K)HIAEEADR(K) & \\
\hline & ES8L1_HUMAN & $\begin{array}{l}\text { Epidermal growth factor } \\
\text { receptor kinase substrate } \\
\text { 8-like protein } 1\end{array}$ & $\begin{array}{c}80.3 / \\
5.66\end{array}$ & 1 & 0.69 & $(\mathrm{~K}) \mathrm{SGPSR}(\mathrm{K})$ & \\
\hline
\end{tabular}


Table 2 Identified Plasma Membrane Protein Spots in 24 h ZEA-treated HL-60 Cells by LC/MS/MS (Continued)

\begin{tabular}{|c|c|c|c|c|c|c|c|}
\hline & gi|16877071 & $\begin{array}{l}\text { ATP synthase, } \mathrm{H}+ \\
\text { transporting, } \\
\text { mitochondrial F1 } \\
\text { complex, gamma } \\
\text { polypeptide } 1\end{array}$ & $\begin{array}{l}32.9 / \\
9.23\end{array}$ & 3 & 11.00 & $\begin{array}{l}\text { R.IYGLGSLALYEK.A } \\
\text { K.HLLIGVSSDR.G } \\
\text { K.ELIEIISGAAALD.- }\end{array}$ & \\
\hline \multirow[t]{2}{*}{16} & LDHB_HUMAN & $\begin{array}{l}\text { L-lactate dehydrogenase } \\
\text { B chain }\end{array}$ & $\begin{array}{c}36.6 / \\
5.64\end{array}$ & 2 & 8.08 & $\begin{array}{l}\text { (K)SLADELALVDVLEDK(L) } \\
\text { (R)VIGSGCNLDSAR(F) }\end{array}$ & -1.62 \\
\hline & AFF4_HUMAN & $\begin{array}{l}\text { AF4/FMR2 family } \\
\text { member } 4\end{array}$ & $\begin{array}{l}12.7 / \\
9.68\end{array}$ & 1 & 0.77 & (K)NSSSTSKQK(K) & \\
\hline \multirow[t]{4}{*}{17} & COMT_HUMAN & $\begin{array}{l}\text { Catechol O- } \\
\text { methyltransferase }\end{array}$ & $\begin{array}{r}30.0 / \\
5.12\end{array}$ & 2 & 14.02 & $\begin{array}{l}\text { (K)VTLWGASQDIIPQLK(K) } \\
\text { (K)GTVLLADNVICPGAPDFLAHVR(G) }\end{array}$ & 1.07 \\
\hline & PODXL_HUMAN & $\begin{array}{l}\text { Podocalyxin like protein } \\
1 \text { precursor }\end{array}$ & $\begin{array}{c}55.6 / \\
5.23\end{array}$ & 1 & 2.46 & (R)LASVPGSQTWVK(E) & \\
\hline & 121944562 & $\begin{array}{l}\text { immunoglobulin A heavy } \\
\text { chain variable region } \\
\text { Homo sapiens }\end{array}$ & $\begin{array}{l}11.9 / \\
5.64\end{array}$ & 1 & 5.50 & $(\mathrm{~K}) \mathrm{VDGIEK}(\mathrm{Y})$ & \\
\hline & TRM13_HUMAN & $\begin{array}{l}\text { tRNA guanosine-2'-O- } \\
\text { methyltransferase TRM13 } \\
\text { homolog }\end{array}$ & $\begin{array}{l}54.2 / \\
8.01\end{array}$ & 1 & 2.49 & (R)KTSLETSNSTTK(R) & \\
\hline \multirow[t]{2}{*}{18} & ANXA1_HUMAN & Annexin A1 & $\begin{array}{c}38.7 / \\
6.63\end{array}$ & 5 & 22.00 & $\begin{array}{l}\text { K.GGPGSAVSPYPTFNPSSDVAALHK.A } \\
\text { K.GVDEATIIDILTK.R } \\
\text { K.ALTGHLEEWLALLK.T } \\
\text { K.TPAQFDADELR.A } \\
\text { K.GTDVNVFNTILTTR.S }\end{array}$ & 3.25 \\
\hline & CN102_HUMAN & $\begin{array}{l}\text { UPF0614 protein } \\
\text { C14orf102 }\end{array}$ & $\begin{array}{l}13.2 / \\
7.60\end{array}$ & 1 & 0.52 & (R)LISLAK(C) & \\
\hline \multirow[t]{3}{*}{19} & SOCS4_HUMAN & $\begin{array}{l}\text { Suppressor of cytokine } \\
\text { signaling } 4\end{array}$ & $\begin{array}{l}50.6 / \\
6.64\end{array}$ & 1 & 1.36 & (R)SDLAFR(W) & -3.12 \\
\hline & K2C1_HUMAN & $\begin{array}{l}\text { Keratin, type II } \\
\text { cytoskeletal } 1(\mathrm{CK}-1)\end{array}$ & $\begin{array}{l}65.8 / \\
8.16\end{array}$ & 4 & 5.00 & $\begin{array}{l}\text { R.QFSSR.S } \\
\text { K.AEAESLYQSK.Y } \\
\text { K.YEELQITAGR.H } \\
\text { K.LALDLEIATYR.T }\end{array}$ & \\
\hline & K2C7_HUMAN & $\begin{array}{l}\text { Keratin, type II } \\
\text { cytoskeletal } 7 \text { (CK-7) }\end{array}$ & $\begin{array}{r}51.2 / \\
5.50\end{array}$ & 1 & 2.00 & K.LALDIEIATYR.K & \\
\hline 20 & gi|189054178 & $\begin{array}{l}\text { unnamed protein } \\
\text { product [Homo sapiens] }\end{array}$ & $\begin{array}{l}66.0 / \\
7.62\end{array}$ & 4 & 6.00 & $\begin{array}{l}\text { R.SLDLDSIIAEVK.A } \\
\text { K.YEELQITAGR.H } \\
\text { K.LNDLEDALQQAK.E } \\
\text { R.TLLEGEESR.M }\end{array}$ & -2.84 \\
\hline \multirow[t]{2}{*}{21} & AF047368_1 & nebulette Homo sapiens & $\begin{array}{l}11.6 / \\
7.98\end{array}$ & 1 & 0.99 & (K)ENQGNISSVK(Y) & 2.99 \\
\hline & ERp29_HUMAN & $\begin{array}{l}\text { Endoplasmic reticulum } \\
\text { protein ERp29 }\end{array}$ & $\begin{array}{l}29.0 / \\
6.77\end{array}$ & 7 & 22.00 & $\begin{array}{l}\text { K.GALPLDTVTFYK.V } \\
\text { K.GALPLDTVTFYK.V } \\
\text { K.FVLVK.F } \\
\text { R.DGDFENPVPYTGAVK.V } \\
\text { K.QGQDNLSSVK.E } \\
\text { K.WAEQYLK.I } \\
\text { K.SLNILTAFQK.K }\end{array}$ & \\
\hline \multirow[t]{2}{*}{22} & ATP5H_HUMAN & $\begin{array}{l}\text { ATP synthase subunit d, } \\
\text { mitochondrial }\end{array}$ & $\begin{array}{l}18.5 / \\
5.21\end{array}$ & 6 & 40.00 & $\begin{array}{l}\text { K.TIDWVAFAEIIPQNQK.A } \\
\text { K.SWNETLTSR.L } \\
\text { R.LAALPENPPAIDWAYYK.A } \\
\text { K.AGLVDDFEK.K } \\
\text { K.YTAQVDAEEK.E } \\
\text { K.YTAQVDAEEKEDVK.S }\end{array}$ & -1.08 \\
\hline & gi|189054178 & $\begin{array}{l}\text { unnamed protein } \\
\text { product }\end{array}$ & $\begin{array}{l}66.0 / \\
7.62\end{array}$ & 3 & 5.00 & $\begin{array}{l}\text { K.SLNNQFASFIDK.V } \\
\text { R.SLDLDSIIAEVK.A } \\
\text { K.LALDLEIATYR.T }\end{array}$ & \\
\hline 23 & B2MG_HUMAN & Beta-2 microglobulin & $\begin{array}{l}12.7 / \\
5.77\end{array}$ & 2 & 18.00 & $\begin{array}{l}\text { R.VNHVTLSQPK.I } \\
\text { K.VEHSDLSFSK.D }\end{array}$ & 1.35 \\
\hline 24 & NDUBA_HUMAN & $\begin{array}{l}\text { NADH dehydrogenase } \\
\text { [ubiquinone] } 1 \text { beta } \\
\text { subcomplex subunit } 10\end{array}$ & $\begin{array}{l}20.8 / \\
8.60\end{array}$ & 3 & 20.35 & $\begin{array}{l}\text { (K)AFDLIVDRPVTLVR(E) } \\
\text { (K)EVEQFTQVAK(A) } \\
\text { (R)YQDLGAYSSAR(K) }\end{array}$ & -1.05 \\
\hline
\end{tabular}


Table 2 Identified Plasma Membrane Protein Spots in 24 h ZEA-treated HL-60 Cells by LC/MS/MS (Continued)

\begin{tabular}{|c|c|c|c|c|c|c|c|}
\hline & gi|189054178 & $\begin{array}{l}\text { unnamed protein } \\
\text { product }\end{array}$ & $\begin{array}{l}65.9 / \\
7.62\end{array}$ & 7 & 12.00 & $\begin{array}{l}\text { R.TNAENEFVTIK.K } \\
\text { R.SLDLDSIIAEVK.A } \\
\text { K.YEELQITAGR.H } \\
\text { K.LNDLEDALQQAK.E } \\
\text { K.LALDLEIATYR.T } \\
\text { R.TLLEGEESR.M } \\
\text { R.GSGGGSSGGSIGGR.G }\end{array}$ & \\
\hline \multirow[t]{2}{*}{25} & ASCC1_HUMAN & $\begin{array}{l}\text { Activating signal } \\
\text { cointegrator } 1 \text { complex } \\
\text { subunit } 1\end{array}$ & $\begin{array}{c}45.48 / \\
5.22\end{array}$ & 1 & 1.75 & (R)SFALLPR(L) & 1.11 \\
\hline & PHB_HUMAN & prohibitin & $\begin{array}{l}29.8 / \\
5.57\end{array}$ & 11 & 52.00 & $\begin{array}{l}\text { K.FGLALAVAGGWNSALYNVDAGHR.A } \\
\text { K.DLQNVNITLR.I } \\
\text { R.FDAGELITQR.E } \\
\text { R.AATFGLILDDVSLTHLTFGK.E } \\
\text { K.EFTEAVEAK.Q } \\
\text { K.QVAQQEAER.A } \\
\text { K.AAIISAEGDSK.A } \\
\text { K.AAELIANSLATAGDGLIELR.K } \\
\text { R.KLEAAEDIAYQLSR.S } \\
\text { K.LEAAEDIAYQLSR.S } \\
\text { R.NITYLPAGQSVLLQLPQ.- }\end{array}$ & \\
\hline \multirow[t]{2}{*}{26} & PHB_HUMAN & Prohibitin & $\begin{array}{l}29.8 / \\
5.57\end{array}$ & 13 & 59.00 & $\begin{array}{l}\text { K.VFESIGK.F } \\
\text { K.DLQNVNITLR.I } \\
\text { R.ILFRPVASQLPR.I } \\
\text { R.IFTSIGEDYDER.V } \\
\text { R.VLPSITTEILK.S } \\
\text { R.FDAGELITQR.E } \\
\text { R.AATFGLILDDVSLTHLTFGK.E } \\
\text { K.EFTEAVEAK.Q } \\
\text { K.QVAQQEAER.A } \\
\text { K.AAIISAEGDSK.A } \\
\text { K.AAELIANSLATAGDGLIELR.K } \\
\text { R.KLEAAEDIAYQLSR.S } \\
\text { R.NITYLPAGQSVLLQLPQ.- }\end{array}$ & 1.06 \\
\hline & NDUS3_HUMAN & $\begin{array}{l}\text { NADH dehydrogenase } \\
\text { [ubiquinone] iron-sulfur } \\
\text { protein 3, mitochondrial }\end{array}$ & $\begin{array}{l}30.2 / \\
6.99\end{array}$ & 2 & 9.00 & $\begin{array}{l}\text { K.SLVDLTAVDVPTR.Q } \\
\text { K.DFPLSGYVELR.Y }\end{array}$ & \\
\hline
\end{tabular}

Note: Spot no. 1, 3, 5, 7, 13 and 14 were matched from our hepatocellular carcinoma cell line database. ${ }^{*}$ The density of spots were calculated as percent volume and shown in this table as folds of increase or decrease (-).

Fusarium [38,39]. In the present study, ZEA induced apoptosis in human leukemic HL-60 and U937 cell lines, but less in PBMCs, as evidenced by presence of apoptotic bodies and cells with subdiploid peaks (representing DNA fragmentation). ZEA is cytotoxic to bovine lymphocytes [40] and induces human PBMC apoptosis and necrosis depending on the concentrations of ZEA [41].

Two central pathways have been shown to be involved in the process of apoptotic cell death: one is the death receptor pathway with direct involvement of caspase- 8 and the other is the mitochondrial pathway in which cytochrome c is released from mitochondria into cytosol. Data presented here suggest that mitochondrial dysfunction is the mechanism involved in ZEA-induced apoptotic death in human leukemic cells. ZEA targets mitochondria and/or lysosomes and induces lipid peroxidation (indicating oxidative stress) and cell death in human colon Caco-2 cell line [42]. The loss of mitochondrial transmembrane potential and the increase of
ROS generation were early events caused by ZEA. The following two possibilities are proposed: (i) ZEA increases ROS production which leads to mitochondrial dysfunction; (ii) Mitochondrial dysfunction is induced by ZEA treatment and results in ROS generation.

Bax, a pro-apoptotic protein in $\mathrm{Bcl}-2$ family, was upregulated indicating the involvement of mitochondria, as Bax forms channels at the outer mitochondrial membrane to facilitate the release of cytochrome c $[43,44]$. Activation of mitochondrial permeability transition is required for the complete release of cytochrome $c$ $[45,46]$. The increased ratios of $\mathrm{Bax} / \mathrm{Bcl}-2$ and $\mathrm{Bax} / \mathrm{Bcl}-$ $\mathrm{xL}$ in ZEA-treated human leukemic cells would facilitate this process. It has been recently reported that ZEAinduced human hepatoma HepG2 cell apoptosis also involves mitochondrial alterations including Bax relocalization into the mitochondrial outer membrane, loss of mitochondrial transmembrane potential, permeability transition pore complex opening, ROS production and cytochrome c release [32]. 


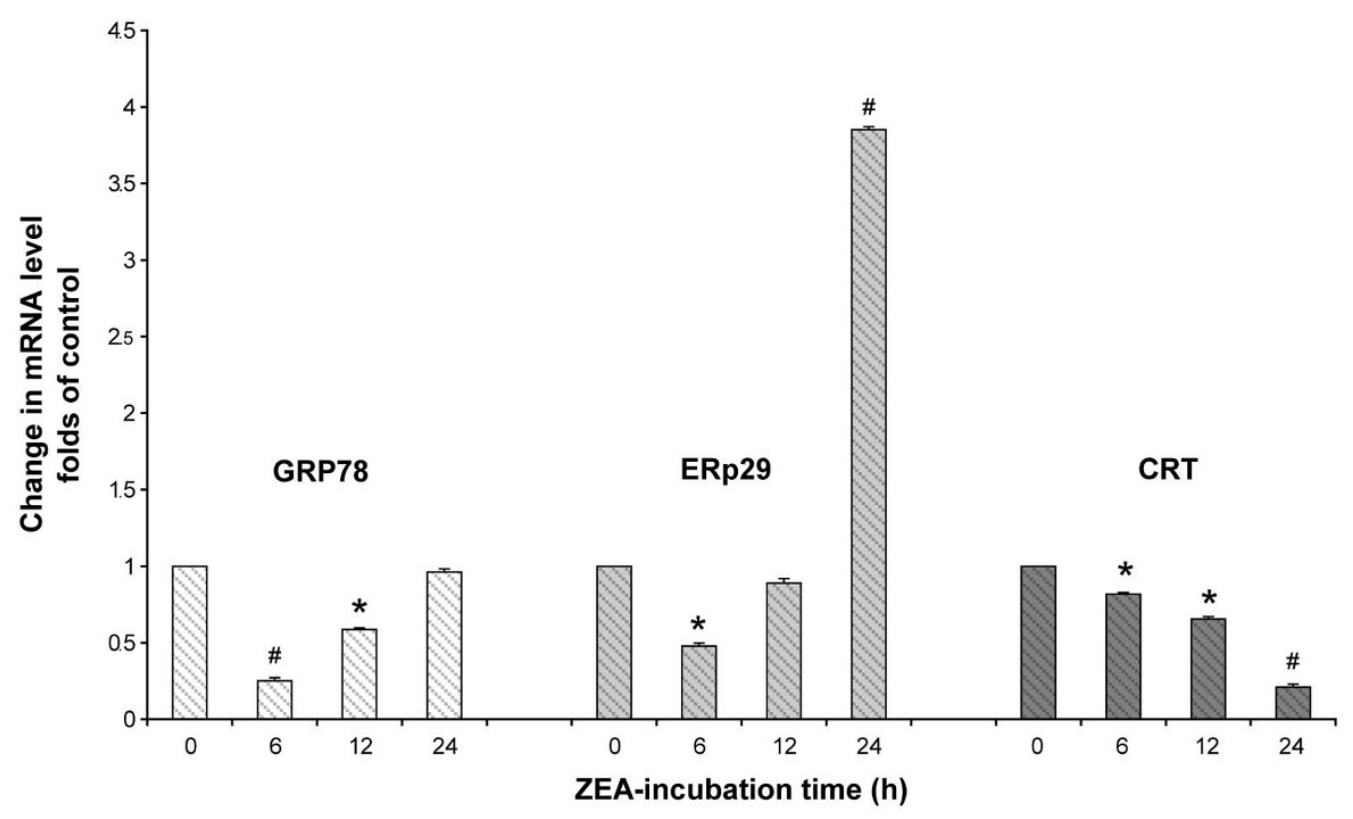

Figure 8 Real-time reverse transcription polymerase chain reaction of GRP78, CRT and ERp29 genes. HL-60 cells were treated with $20 \mu \mathrm{g} /$ $\mathrm{ml}$ ZEA for indicated time of incubation. The levels of mRNA were normalized to the level of GAPDH mRNA. After the normalization, the mRNA level was expressed as the fold change compared to that in the basal group untreated with ZEA (at 0 h). Data are the mean \pm S.E.M. of three independent experiments. * $p<0.05$ compared to control, \# $p<0.01$ compared to control.

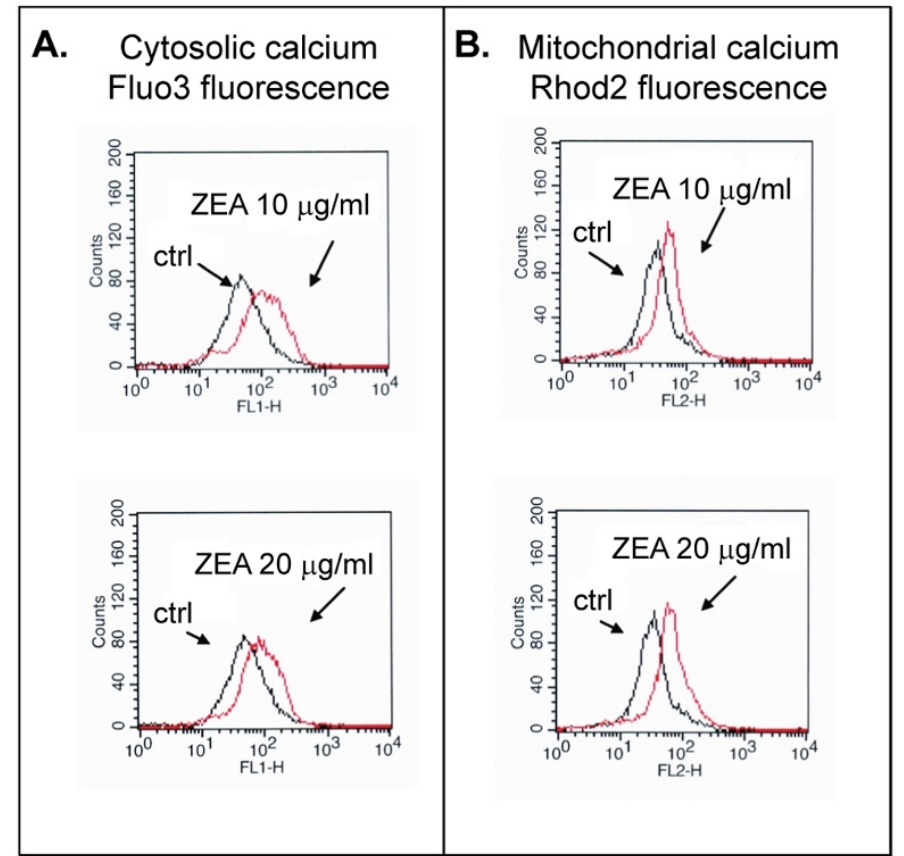

Figure 9 Effect of ZEA on cytosolic (A) and mitochondrial (B) Ca ${ }^{2+}$ level in HL-60 cells. HL-60 cells were incubated with Fluo3 (cytosolic) or Rhod2 (mitochondrial) $\mathrm{Ca}^{2+}$ - specific dye for $15 \mathrm{~min}$ after treatment with and without ZEA for $1 \mathrm{~h}$, then were subjected to flow cytometry as described in Materials and Methods. Black trace, control cells; red trace, ZEA-treated cells. Histogram of FACS analysis represents one of three independent experiments. 


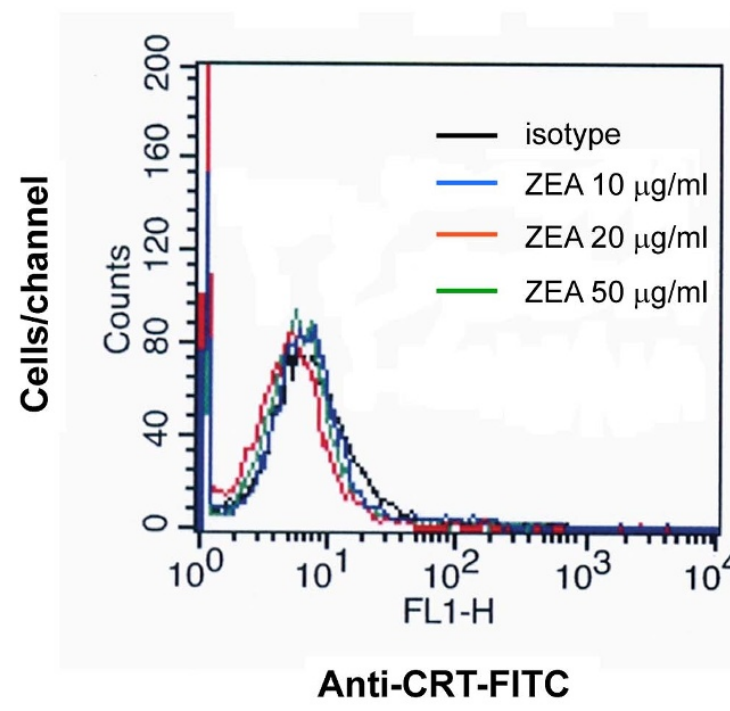

Figure 10 Cell surface exposure of calreticulin in ZEA-treated HL-60 cells. Cells were treated for 30 min with ZEA at indicated concentrations and analyzed for the caltreticulin exposure by flow cytometry as described in Materials and Methods. Histogram of FACS analysis represents one of three independent experiments.

Proteomic profiling of ZEA-treated and untreated U937 cells revealed a role of enzymes in carbohydrate and nucleotide metabolism in apoptosis. Besides its role in glycolysis, GAPDH initiates a cell death cascade [47]. Diverse apoptotic stimuli activate inducible nitric oxide synthase (iNOS) or neuronal NOS (nNOS), with the NO S-nitrosylating GAPDH, abolishing its catalytic activity and conferring on it the ability to bind to Siah1, an E3ubiquitin-ligase with a nuclear localizing signal. The GAPDH-Siah1 protein complex, in turn, translocates to the nucleus and mediates cell death.

The involvement of ER stress in ZEA-induced apoptosis shown in this study led to an investigation of CRT, an ER-resident stress-regulated chaperone with C-terminal KDEL signal $[48,49]$. Under certain circumstances, ER dysfunction leads to an accumulation of unfolded or misfolded proteins in the ER lumen and activates compensatory mechanism, which has been referred to as ER stress response or unfolded protein response [50]. Several ER transmembrane proteins are identified as sensors of ER stress. These include pancreatic ER kinase (PERK), inositol requiring enzyme 1 (IRE1) and activating transcription factor 6 (ATF6). PERK phosphorylates the alpha subunit of eukaryotic initiation factor 2 (eIF2alpha), which attenuates the initiation of translation in response to ER stress. The activation of IRE1 and ATF6 signaling promotes pro-apoptotic transcription factor $\mathrm{CHOP}$ and the expression of ER-localized chaperones, such as CRT, GRP78 and GRP94, which facilitate the restoration of proper protein folding within the ER [50]. These protective responses result in an overall decrease in translation, enhanced protein degradation and increased levels of ER chaperones, which consequently increase the protein folding capacity of the ER. However, sustained ER stress ultimately leads to decreased ER chaperone and cell death [50]. CRT was translocated to the cell membrane of human leukemic cells treated with ZEA (Figure 7B). ER also regulates calcium ion homeostasis and $\mathrm{Ca}^{2+}$ levels were increased in cytosol and mitochondria, suggesting the involvement of ER stress in ZEA-treated human leukemic cells. 2DPAGE of HL-60 treated cells showed increased expression of GRP78, ERp29 and CRT precursor confirming the existence of ER stress. Real-time reverse transcription PCR supported the involvement of ERp29 in the human leukemic HL-60 cell apoptosis. For CRT and GRP78 gene expression, the mRNA might not be stable and was degraded at the measured-time. Nevertheless, ER stress can also activate caspase- 9 by releasing cytochrome c from mitochondria to cytosol $[24,25]$.

The accumulation of unfolded proteins in the ER was a marker of cellular stress induced by ZEA. Oxidative stress was also found in ZEA-stimulated human leukemic cell apoptosis (Figure 5). The involvement of ER stress and oxidative stress in ZEA-induced apoptosis of human leukemic cell lines are first described, however, further experiments are required to demonstrate the signaling relationship between the oxidative stress and ER stress.

The contents of ZEA in the daily intake might enhance the apoptotic effect of promyelocytic and monocytic leukemic cell lines in the leukemic patients. ZEA-induced apoptosis and necrosis occur in human PBMCs in vitro depending on the concentrations of ZEA [41]. The major metabolites of ZEA in various species are alpha and beta zearalenol. Alpha and beta zearalenol inhibit cell viability and induce oxidative stress and stress protein (HSP70 and HSP27) expression in Vero cells (kidney epithelial cells extracted from African green monkey) [51]. However, more studies should be performed in in vivo model before using ZEA as a therapeutic drug.

Taken together, the intrinsic (mitochondrial) and ER stress pathways cooperated in ZEA-induced human leukemic cell apoptosis. An understanding of the mechanism of ZEA-activated leukemic cell death is a basic step in clinical therapeutic approaches.

\section{Acknowledgements}

This work was financially supported by Thailand Research Fund (TRF) and Commission of Higher Education (CHE), grant No. RMU5080003. We thank Prof. Prapon Wilairat for editing the manuscript. 


\section{Author details}

'Department of Biochemistry, Faculty of Medicine, Chiang Mai University, Chiang Mai 50200, Thailand. '2Laboratory of Biochemistry, Chulabhorn Research Institute, Bangkok 10210, Thailand. ${ }^{3}$ Department of Biochemistry, Faculty of Science, Mahidol University, Rama VI Road, Bangkok 10400, Thailand.

\section{Authors' contributions}

$\mathrm{RB}, \mathrm{OK}$ and PK conceived, designed and implemented the study, and drafted the manuscript. The 2-D PAGE coupled with LC-MS/MS analysis were performed and supervised by DC, PS, CS and JS. All authors read and approved the final draft of the manuscript.

\section{Competing interests}

The authors declare that they have no competing interests.

Received: 26 October 2010 Accepted: 30 December 2010 Published: 30 December 2010

\section{References}

1. Nikov G, Hopkins N, Boue S, Alworth WL: Interactions of dietary estrogens with human estrogen receptors and the effect on estrogen receptorestrogen response element complex formation. Environ Health Perspect 2000, 108:867-872

2. Kuiper GG, Lemma JG, Carlsson B, Corton JC, Safe SH, van der Saag PT, van der Burg B, Gustafsson JA: Interaction of estrogenic chemicals and phytoestrogens with estrogen receptors (beta). Endocrinology 1998, 139:4252-4263.

3. Janardhana GR, Rabeas KA, Shekar Shetty H: Mycotoxin contamination of maize grains grown in Karnataka (India). Food Chem Toxicol 1999, 37:863-868.

4. Okoye ZS: Stability of zearalenone in naturally contaminated corn during Nigerian traditional brewing. Food Addit Contam 1987, 4:57-59.

5. Reza Oveisi M, Hajimahmoodi M, Memarian S, Sadeghi N, Shoeibi S: Determination of zearalenone in corn flour and a cheese snack product using high-performance liquid chromatography with fluorescence detection. Food Addit Contam 2005, 22:443-448.

6. Minervini F, Giannoccaro A, Cavallini A, Visconti A: Investigations on cellular proliferation induced by zearalenone and its derivatives in relation to the estrogenic parameters. Toxicol Lett 2005, 159:272-283.

7. Abid-Essefi S, Baudrimont I, Hassen W, Ouanes Z, Mobio TA, Anane R, Creppy EE, Bacha H: DNA fragmentation, apoptosis and cell cycle arrest induced by zearalenone in cultured DOK, Vero and Caco-2 cells: prevention by vitamin E. Toxicology 2003, 192:237-248

8. Ayed-Boussema I, Bouaziz C, Rjiba K, Valenti K, Laporte F, Bacha H, Hassen W: The mycotoxin Zearalenone induces apoptosis in human hepatocytes (HepG2) via p53-dependent mitochondrial signaling pathway. Toxicol In Vitro 2008, 22:1671-1680

9. Dias N, Bailly C: Drugs targeting mitochondrial functions to control tumor cell growth. Biochem Pharmacol 2005, 70:1-12.

10. Schulze-Osthoff K, Ferrari D, Los M, Wesselborg S, Peter M: Apoptosis signaling by death receptors. Eur J Biochem 1998, 254:439-459.

11. Rao RV, Ellerby HM, Bredesen DE: Coupling endoplasmic reticulum stress to the cell death program. Cell Death Differ 2004, 11:372-380.

12. Budihardjo I, Oliver H, Lutter M, Luo X, Wang X: Biochemical pathways of caspase activation during apoptosis. Annu Rev Cell Dev Biol 1999, 15:269-290.

13. Li UX, Kim CN, Yang J, Jemmerson R, Wang X: Induction of apoptotic program in cell-free extracts: requirement for dATP and cytochrome $c$. Cell 1996, 86:147-157.

14. Thorburn A: Death receptor-induced cell killing. Cell Signal 2004 16:139-144.

15. Boyce M, Yuan J: Cellular response to endoplasmic reticulum stress: a matter of life or death. Cell Death Differ 2006, 13:363-373.

16. Yamaguchi $\mathrm{H}$, Wang HG: CHOP is involved in endoplasmic reticulum stress-induced apoptosis by enhancing DR5 expression in human carcinoma cells. J Biol Chem 2004, 279:45495-45502.

17. Johnson S, Michalak M, Opas M, Eggleton P: The ins and outs of calreticulin: from the ER lumen to the extracellular space. Trends Cell Biol 2001, 11:122-129.
18. Michalak M, Corbett EF, Mesaeli N, Nakamura K, Opas M: Calreticulin: one protein, one gene, many functions. Biochem J 1999, 344:281-292.

19. Gardai SJ, MCPhillips KA, Frasch SC, Janssen WJ, Starefeldt A, MurphyUllrich JE: Cell surface calreticulin initiates clearance of viable or apoptotic cells through transactivation of LRP on the phagocyte. Cell 2005, 123:321-334

20. Obeid M, Tesniere A, Ghringhelli F, Fimia GM, Apetoh L, Perfettini JL: Calreticulin exposure dictates the immunogenicity of cancer cell death. Nat Med 2007, 13:54-61.

21. Apetoh L, Ghringhelli F, Tesniere A, Obeid M, Ortiz C, Criolo A: Toll-like receptor 4-dependent contribution of the immune system to anti-cancer chemo- and radiotherapy. Nat Med 2007, 13:1050-1059.

22. Casares N, Pequignot MO, Tesniere A, Ghringhelli F, Roux S, Chaput N: Caspase-dependent immunogenicity of doxorubicin-induced tumor cell death. J Exp Med 2005, 202:1691-1701.

23. Srivastava PK: Heat shock protein-based novel immunotherapies. Drug News Perspect 2000, 13:517-522.

24. Momoi T: Caspases involved in ER stress-mediated cell death. J Chem Neuroanat 2004, 28:101-105.

25. Jimbo A, Fujita E, Kouroku Y, Ohnishi J, Inohara N, Kuida K, Sakamaki K, Yonchara S, Momoi T: ER stress induces caspase-8 activation, stimulating cytochrome c release and caspase-9 activation. Exp Cell Res 2003, 283:156-166.

26. Su WC, Chang SL, Chen TY, Chen JS, Tsao CJ: Comparison in in vitro growth-inhibitory activity of carboplatin and cisplatin on leukemic cells and hematopoietic progenitors: the myelosuppressive activity of carboplatin may be greater than its antileukemic effect. Jpn J Clin Oncol 2002, 30:562-567.

27. Livak KJ, Schmittgen TD: Analysis of relative gene expression data using real-time quantitative PCR and the 2(-Delta Delta C(T)) Method. Methods 2001, 25:402-408.

28. Gottlieb E, Armour SM, Harris MH, Thompson CB: Mitochondrial membrane potential regulates matrix configuration and cytochrome $c$ release. Cell Death Differ 2003, 10:709-717.

29. Roucou X, Montessuit S, Antonsson B, Martinou JC: Bax oligomerization in mitochondrial membranes requires tBid (caspase-8-cleaved Bid) and a mitochondrial protein. Biochem J 2002, 368:915-921.

30. Scorrano L, Korsmeyer SJ: Mechanisms of cytochrome $\mathrm{c}$ release by proapoptotic BCL-2 family members. Biochem Biophys Res Commun 2003, 304:437-444.

31. Korsmeyer SJ, Wei MC, Saito M, Weiler S, Oh KJ, Schlesinger PH: Proapoptotic cascade activates BID, which oligomerizes BAK or BAX into pores that result in the release of cytochrome c. Cell Death Differ 2000, 7:1166-1173.

32. Bouaziz C, Sharaf El Dein O, El Golli E, Abid-Essefi S, Brenner C, Lemaire C Different apoptotic pathways induced by zearalenone, T-2 toxin and ochratoxin A in human hepatoma cells. Toxicology 2008, 254:19-28.

33. Bizyukin AV, Korkina LG, Velichkovskii BT: Comparative Use of 2,7dichlorofluorescin diacetate, dihydrorhodamine 123 , and hydroethidine to study oxidative metabolism in phagocytic cells. Bull Eksp Biol Med 1995, 119:347-351.

34. Silveira $L R$, Pereira-Da-Silva $L$, Juel $C$, Hellsten $Y$ : Formation of hydrogen peroxide and nitric oxide in rat skeletal muscle cells during contractions. Free Radic Biol Med 2003, 35:455-464.

35. Picard D: Heat-shock protein 90 , a chaperone for folding and regulation. Cell Mol Life Sci 2002, 59:1640-1648.

36. Zhang D, Armstrong JS: Bax and the mitochondrial permeability transition cooperate in the release of cytochrome $\mathrm{c}$ during endoplasmic reticulum-stress-induced apoptosis. Cell Death Differ 2007, 14:703-715.

37. Tufi R, Panaretakis T, Bianchi K, Criollo A, Fazi B, Di Sano F, Tesniere A, Kepp O, Paterlini-Brechot P, Zitvogel L, Piacentini M, Szabadkai G, Kroemer G: Reduction of endoplasmic reticulum calcium ion levels favors plasma membrane surface exposure of calreticulin. Cell Death Differ 2007, 14:1-9.

38. D'Mello JPF, Placinta CM, MacDonald AMC: Fusarium mycotoxins: a review of global animal health, welfare and reproductivity. Anim Feed Sci Technol 1999, 78:183-205.

39. Minervini F, Dell'Aquila ME, Maritato F, Minoia P, Visconti A: Toxic effects of the mycotoxin zearalenone and its derivatives on in vitro maturation of bovine oocytes and 17[beta]-estradiol levels in mural granulosa cell cultures. Toxicol In Vitro 2001, 15:489-495. 
40. Lioi MB, Santoro A, Barbieri R, Salzano S, Ursini MV: Ochratoxin A and zearalenone: a comparative study on genotoxic effects and cell death induced in bovine lymphocytes. Mutat Res 2004, 557:19-27.

41. Vlata Z, Porichis F, Tzanakakis G, Tsatsakis A, Krambovitis E: A study of zearalenone cytotoxicity on human peripheral blood mononuclear cells. Toxicol Lett 2006, 165:274-281.

42. Kouadio JH, Mobio TA, Baudrimont I, Moukha S, Dano SD, Creppy EE: Comparative study of cytotoxicity and oxidative stress induced by deoxynivalenol, zearalenone or fumonisin B1 in human intestinal cell line Caco-2. Toxicology 2005, 213:56-65.

43. Jürgensmeier JM, Xie Z, Deveraux Q, Ellerby L, Bredesen D, Reed J: Bax directly induces release of cytochrome $\mathrm{c}$ from isolated mitochondria. Proc Natl Acad Sci USA 1998, 95:4997-5002.

44. Antonsson B, Montessuit S, Lauper S, Eskes R, Martinou JC: Bax oligomerization is required for channel-forming activity in liposomes and to trigger cytochrome c release from mitochondria. Biochem J 2000, $345: 271-278$

45. Yang JC, Cortopassi GA: Induction of the mitochondrial permeability transition causes release of the apoptogenic factor cytochrome c. Free Radic Biol Med 1998, 24:624-631.

46. Bradham CA, Qian T, Streetz K, Trautwein C, Brenner DA, Lemasters JJ: The mitochondrial permeability transition is required for tumor necrosis factor alpha-mediated apoptosis and cytochrome c release. Mol Cell Biol 1998, 18:6353-6364.

47. Hara MR, Agrawal N, Kim SF, Cascio MB, Fujimuro M, Ozeki Y, Takahashi M, Cheah MJH, Tankou SK, Hester LD, Ferris CD, Hayward SD, Snyder SH, Sawa A: S-nitrosylated GAPDH initiates apoptotic cell death by nuclear translocation following Siah1 binding. Nat Cell Biol 2005, 7:665-674.

48. Munro S, Pelham HR: A C-terminal signal prevents secretion of luminal ER proteins. Cell 1987, 48:899-907.

49. Pelham HR: Evidence that luminal ER proteins are sorted from secreted proteins in a post-ER compartment. EMBO J 1988, 7:913-918.

50. Xu C, Bailly-Maitre B, Reed JC: Endoplasmic reticulum stress: cell life and death decision. J Clin Invest 2005, 115:2656-2664.

51. Othmen ZO, Golli EE, Abid-Essefi S, Bacha H: Cytotoxicity effects induced by Zearalenone metabolites, alpha Zearalenol and beta Zearalenol, on cultured Vero cells. Toxicology 2008, 252:72-77.

doi:10.1186/1756-8722-3-50

Cite this article as: Banjerdpongchai et al:: Mitochondrial and endoplasmic reticulum stress pathways cooperate in zearalenoneinduced apoptosis of human leukemic cells. Journal of Hematology \& Oncology 2010 3:50.

\section{Submit your next manuscript to BioMed Central and take full advantage of:}

- Convenient online submission

- Thorough peer review

- No space constraints or color figure charges

- Immediate publication on acceptance

- Inclusion in PubMed, CAS, Scopus and Google Scholar

- Research which is freely available for redistribution 